\title{
1 Bred in the Exchange: Seamstresses and Shopkeepers
}

\section{Ann Gray and Sarah Frost}

In the late seventeenth century, the shops of the Royal Exchange housed many of the apprentice seamstresses in London's companies. One of them was Ann Gray, whose mistress, Sarah Cleave, drove a 'considerable trade' in her shop in the Royal Exchange in 'costly laces and other things'. Sarah Cleave was a single woman who had earned the freedom of London after her own apprenticeship, and Ann was her second apprentice. Seamstresses and shopkeepers like these worked in shops, stalls and houses across the City and Westminster and in the shopping galleries of the Royal Exchange, whose small, prestigious shops proved particularly attractive to the middling and gentry women who joined the City companies in the late seventeenth century. Even with an interrupted training, young women like Ann Gray readily went on to make a living at sewing, but their apprenticeships, work and subsequent lives have left little record, and the story of London's consumption revolution has focused more on goods and shoppers than their female makers and sellers. Litigation like that brought by Ann's family to recoup the costs of her abandoned apprenticeship is a rare and eloquent source.

Sarah Cleave's flourishing business in the Exchange looked promising to her new apprentice, Ann Gray, until Cleave made plans to marry a scrivener, William Frost, and the Grays lost faith that her business would carry on. Ann's brother George Gray claimed that Sarah's trade was reduced. She was dealing in gauze and bone lace but not in point and 'other costly laces', 'nor doth she drive soe considerable a trade as she did before her intermarriage ... but doth decline the same very much \& not mind her shop at all'. She had scarcely any goods, he claimed, to run a business. George confronted William Frost, asking how he planned to provide for his wife-to-be's apprentice: he received the non-committal reply that 'he would provide for her as he thought fit'. Ann Gray offered her services instead to another Exchange seamstress, Katherine Bobart, and left the Frosts two years into her contract. Sarah and William Frost 
continued to take a few apprentices, male and female, over the next thirteen years, suggesting that Exchange business waxed and waned with trade conditions as much as marital choices. ${ }^{1}$ Their negotiations illuminate the female-dominated retail world of the Royal Exchange in the late seventeenth century and the interpersonal and spatial connections that governed its trade.

At the Mayor's Court, witnesses described Ann Gray's transgressions of the apprentice code. The Frosts alleged that Ann, working in Sarah's shop, had allowed customers to buy on credit and had either kept the money or not pursued the debt. Katherine Bobart came to explain that she had refused to take Ann on herself. Although she believed Ann to be already a capable worker, worth being paid wages as well as diet and lodging, she had heard that her brother was 'a contentious person' and that Ann 'owed money to several persons on the Exchange', as well as to Katherine herself and her servant. Ann's dubious transactions, and her brother's contentiousness, established a reputation for them 'on the Exchange'.

Two other young women came to testify about Ann Gray's misdealings. Elizabeth Spencer, a twenty-one-year-old servant to a threadman, described Ann's misuse of credit. Visiting Sarah's shop in the upper galleries of the Exchange, Elizabeth Spencer had bought 'a gauze pass for the head', an elaborately woven head covering, from Ann for 14 pence on credit. Evidently, strolling in the Exchange did not require ready cash. Elizabeth returned to the shop subsequently and told Sarah Frost she would repay her debt later; but when, on a third visit to the Exchange, she saw Ann Gray, she decided to pay her only 2 pence, because Ann already owed her a shilling (12 pence). Ann argued, because she had been sick and did not have a shilling to pay her mistress herself, and she kept the transaction secret. It emerged, of course, when Elizabeth saw Sarah Frost again, asked if the apprentice had paid her and discovered Sarah had had none of the money. This was one of the breaches of trust of which Sarah complained. Credit, in this transaction, was contested; Ann's use of it as an apprentice was dubious, nor was she entrusted to give credit to customers. The repeated encounters of the protagonists, circulating around the tightly packed space of the Exchange, made discovery inevitable. Others went further: Sarah Stables, another shopkeeper, had Ann Gray arrested for debt for buying things on credit and never paying. Visiting Ann in the 'prison house', presumably in the hope of getting the debt settled before formal proceedings began, Sarah found Ann's master, William Frost, also there, confronting Ann with a bill he produced from his pocket. He told Ann to

${ }^{1}$ ROLLCO, Sarah Cleeve, William Frost. 
read it, but she refused. Sarah read it for her 'and seeing one particular therein being a sute of French Colebertine asked the Complainant [Ann], What she had to doe with any such sort of thing?' 'Is that there?' parried Ann and told her it was paid for. ${ }^{2}$ Colbertine was the fashionable lace made at the royal lace enterprise, instigated by Colbert, at Alençon, its name featuring in the 'Fop's Dictionary' and Congreve's Way of the World. ${ }^{3}$ Its trimming on a suit of clothes was not what an apprentice, however aspirational, should have been wearing, though it epitomised Exchange fashion.

Ann's acquisition on credit of the Colbertine suit was part of a series of transactions between the apprentice, her associates and shopkeepers on the Exchange, which indicates how apprentices might become enmeshed in the micro-economy of credit there. Women were heavily represented in London debtors' prisons, reflecting the prominent role of single and married women in London's business world; a quarter of the prisoners of the late seventeenth-century Sheriff's Court were female. ${ }^{4}$ As part of her induction into the world of trade, Ann Gray was at risk of abusing credit both as a customer and as a shopkeeper. The majority of transactions in seventeenth-century shops involved credit, and the capacity to judge it was central to a shopkeeper's skills. Here, the rules of engagement in consumption were being crafted between shopkeepers and shoppers, and the Royal Exchange - a hub of prestigious leisure shopping - was developing rules of its own.

The Royal Exchange was itself a forum for credit, a place where business relationships were brokered. Sarah Frost's shop was upstairs, in the rows of tiny shops that lined the upper gallery. Downstairs, merchants met to trade in the Exchange's open quadrangle. They dealt in luxury goods from abroad, but sometimes also with stocks and bills of exchange, stigmatised by Defoe and others as fundamentally untrustworthy. ${ }^{5}$ In the upstairs shops, too, women's shopkeeping activity was part of a metropolitan circulation of money, credit, goods and reputation, centring women as consumers and workers.

${ }^{2}$ LMA, CLA/024/05/493 (1689). On the wider role of women in providing credit, see Judith Spicksley, "Fly with a Duck in Thy Mouth": Single Women as Sources of Credit in Seventeenth Century England', Social History 32, no. 2 (2007): 187-207 and Craig Muldrew, The Economy of Obligation: The Culture of Credit and Social Relations in Early Modern England (London: Palgrave Macmillan, 1998).

${ }^{3}$ Fanny Bury Palliser, A History of Lace (London: Sampson Low, Marston, Low \& Searle, 1875), 303; Samuel Johnson, A Dictionary of the English Language (London: Longman, Rees, Orme, 1827).

4 Craig Muldrew, "A Mutual Assent of Her Mind"? Women, Debt, Litigation and Contract in Early Modern England', History Workshop fournal 55 (2003): 56.

${ }^{5}$ Natasha Glaisyer, The Culture of Commerce in England, 1660-1720 (Woodbridge: Boydell \& Brewer, 2006), 57. 
The dispute over Ann Gray's abandoned apprenticeship exposes contests in the Exchange over credit, shopkeeping conduct, City custom and married women's work. This chapter examines those issues through the spatial arrangements of the Exchange and its networks of business and credit, drawing on the Gresham Repertories which recorded Exchange business, litigation and tax records. The Exchange was laden with spatial and symbolic significance, both for merchants and for female shopkeepers and shoppers: looking at its people and transactions more closely will enable us to connect new practices of consumption with the daily experience of women as workers and shoppers. More broadly, Ann Gray and Sarah Cleave are exemplars of the women who made a network of apprenticeship for seventeenth-century London. They laid the groundwork for a new sort of consumerism. Their apprenticeships trained them for the productive working lives that were characteristic of seventeenthcentury women from a range of social origins. Around them, in London's variety of shops and housing, were girls from poverty to gentry, sewing for a living. This book starts with the shops in which girls and women were 'bred in the Exchange'.

\section{Building the Royal Exchange}

In Wenceslaus Hollar's set of four seasonal images of English women, a fantasy of 'Winter' poses in front of a City backdrop, dressed in robes, fur, high heels, hood and a half-mask to protect the complexion (Figure 1.1). Her clothes reflect the luxury shops of mid-seventeenthcentury London; everything she wore could be bought nearby. Pictured at the corner of Cheapside and Cornhill, she is flanked on the left-hand side by the established style of shop, with front shutters that folded down to display the goods inside, and doors for public access. On her right, the Royal Exchange, with its tower and facade, offers a different model: a merchants' exchange in a quadrangle below and galleries of tiny stalls surrounding it above. Shopping galleries like this were pivotal in the development of women's businesses in late seventeenth-century London.

The Royal Exchange was not only the original Stock Exchange but the first of London's shopping galleries. ${ }^{6}$ It followed the Exchanges of Paris, Amsterdam and Antwerp, where purpose-built, covered walkways of small shops sat alongside law courts and stock exchanges, and it was meant to put London on the mercantile map with an equivalently protected trading centre. The shop part upstairs, the 'pawn' (after the Dutch

${ }^{6}$ William C. Baer, 'Early Retailing: London's Shopping Exchanges, 1550-1700', Business History 49, no. 1 (2007): 29-51. 


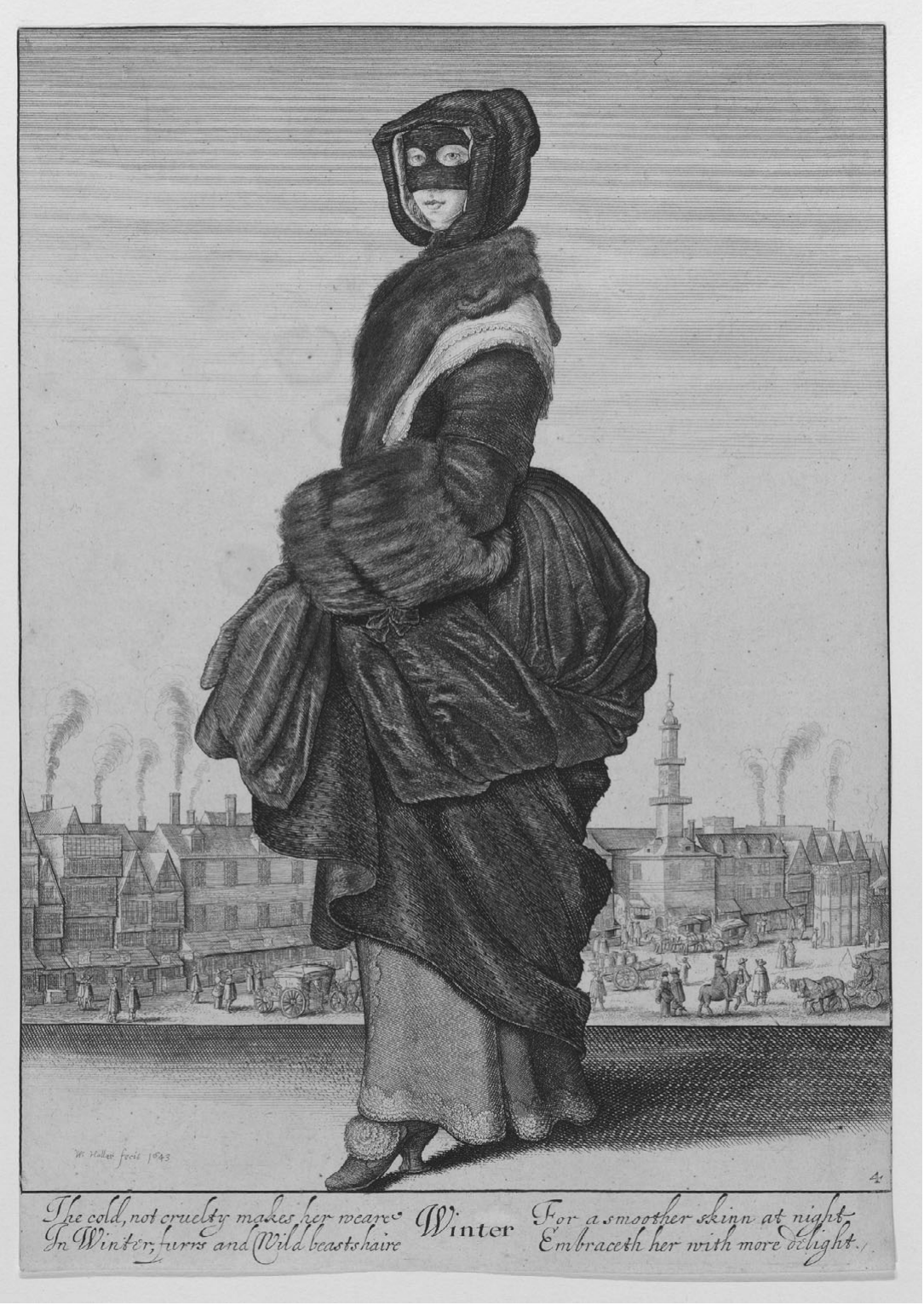

Figure 1.1 Wenceslaus Hollar, Winter (1643-4). $26 \times 18 \mathrm{~cm}$. Metropolitan Museum of Art, NY, CC. 
baan, for pathway), was built on a model also used in Westminster Hall, the New Exchange on the Strand and the Middle and Exeter Exchanges, with stalls, 'boxes' or booths along a walk where shoppers could browse in comfort. They were an attraction in themselves, picked out in guidebooks and drama as the epitome of urban style, consumption and sociability. While the buildings were grand and lavishly decorated, the shops themselves were simple wooden structures: all the originality and excitement were in the exotic and fashionable goods they sold. ${ }^{7}$ Contemporary satire also marked the role of women as both shoppers and shopkeepers, and from the mid-seventeenth century, the 'exchangewoman' featured as a focus of sexualised denigration in plays and satires. Hollar's Winter endorses the sexualisation of consumption: beneath her rosetted shoe, lines read, 'The cold, not cruelty makes her weare / In Winter, furrs and Wild beasts haire / For a smoother skinn at night / Embraceth her with more delight'. The verse alludes glancingly both to the erotics of fur and folk tales of shrewish women subdued by being beaten and wrapped in salted animal skins. ${ }^{8}$ Along with the four other shopping galleries of late seventeenth-century London, the Exchange represented a new, specialised marketplace, to which the fashions, desires and labours of women were central.

Each Exchange had its own character. Westminster Hall's shops, laid out around the outside of the formal space occupied by law courts, sold books, legal supplies, lozenges for the attorneys' and MP's voices, and millinery. The three clustered around the Strand (Figure 1.2) were the most associated with sexual transactions in satire if not in actuality; Strype's Survey of London described the short-lived Middle Exchange as a 'Whores-Nest'. ${ }^{9}$ There, the dynamics of class, appearance and sexual libertinage combined to undermine reputations. A pamphlet exchange dramatised the question of whether the 'ape-gentlewomen' shopkeepers of the New Exchange were 'really' gentry or whether their descent into trade, from displaced clergy parents or dislocated county gentry, left them irretrievably damaged. ${ }^{10}$ The issue of women's shopkeeping at this

7 Claire Walsh, 'Social Meaning and Social Space in the Shopping Galleries of Early Modern London', in A Nation of Shopkeepers: Five Centuries of British Retailing, ed. John Benson and Laura Ugolini (London: I. B. Tauris, 2003), 52-79.

8 See, for example, Joannes Bramis, Here Begynneth a Merry Ieste of a Shrewde and Curste Wyfe, Lapped in Morrelles Skin, for Her Good Behauyour (1580); for more on Hollar's furs, see Julia V. Emberley, Venus and Furs: The Cultural Politics of Fur (London: I. B. Tauris, $1998), 110-23$. The verse is anonymous.

9 John Strype, Survey of London (1720), book 4, chapter 7.

10 Ape-Gentle-Woman, or, The Character of an Exchange-Wench (1675); An Answer to the Character of an Exchange-Wench, or, A Vindication of an Exchange-Woman (1675); Will 


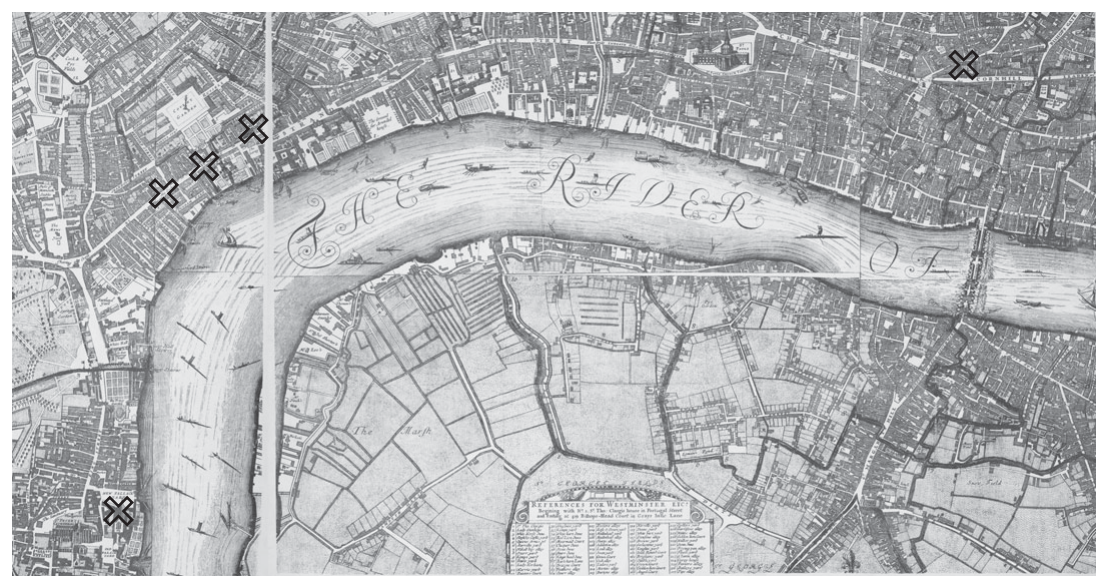

Figure 1.2 Sites of the shopping galleries. Left to right: Westminster Hall, New Exchange, Middle Exchange, Exeter Exchange and Royal Exchange.

Map: Morgan, London Actually Surveyed (1682), London Topographic Society 1904. Wikicommons/Library of Congress (annotations added).

juncture and in this place touched a nerve because it involved gentility and professional aspirations.

The location of the Royal Exchange, in contrast, connected it to merchants, guilds and apprenticeship. Natasha Glaisyer's analysis of England's late seventeenth-century culture of commerce puts the Exchange at the heart of London's self-image, particularly as it was renovated after the Fire. ${ }^{11}$ The intellectual community of the city also interwove mercantile interest with cultural exchanges. While most historical attention to the Exchange has examined the role it played for the merchants who used its downstairs, this chapter argues for the significance of its upper galleries, where women worked and shopped, and, in doing so, it rewrites the Exchange and its surroundings to include its community of female work. ${ }^{12}$ The shops of the upper pawn were key to the development of female apprenticeship amongst gentry and middling girls and the enterprise of mistresses, and they also illuminate the whole

Pritchard, Outward Appearances: The Female Exterior in Restoration London (Lewisburg: Bucknell University Press, 2008), chapter 5.

11 Glaisyer, Culture of Commerce.

12 Amy Louise Erickson, 'Eleanor Mosley and Other Milliners in the City of London Companies 1700-1750', History Workshop fournal 71 (2011): 147-72, discusses women at the eighteenth-century Exchange. 
issue of gender and consumption from a different angle - that of the shopkeeper. The name 'exchangewoman' appears both in the satires of the New Exchange and in the tax records of the Royal Exchange: its satirical exploitation should not be allowed to undermine the real significance of shop work. ${ }^{13}$ Rather, the Exchange's critical location in the middle of the City placed women's business in the heart of mainstream mercantile exchange, enabling stallholders to represent themselves as respectable and elite businesswomen. Across eighteenth-century towns and cities, Deborah Simonton argues, the elite end of the needle trade constituted a profession, supported by strategic shop locations at the heart of Edinburgh, Bath and Colchester, as well as London. ${ }^{14}$ The Royal Exchange, established before shops moved away from the City to the West End, helped inaugurate this model of women's shops.

At the Exchange's heart, both before and after the Fire, was the trading floor where merchants met, an irregular quadrangle framed by an arcaded entrance, carved staircases and statuary, with a number of shops along the sides (Figure 1.3). Less attention has been paid to the shops on the upper storey. ${ }^{15}$ However, they were crucial to the Exchange's economy: the building's upkeep depended on the rents of milliners and linen drapers. Spatially, too, the shops were part of the Exchange's daily life. Visitors to the shops crossed the trading floor to reach the stairs. The most desirable shops looked out and down onto it, and balconies on the inner side allowed shoppers to look down onto those below. The twicedaily bells to signal trading time, and the four different tunes played by the clock after the Fire, rang through the pawns as well as the piazza. The shops were there to make profits to keep the building going. The women who tenanted them and shopped there were not segregated from the downstairs merchants but shared on unequal terms in the Exchange's project.

The upper pawn, where the majority of women kept their shops in the late seventeenth century, consisted of rows of small shops arranged around passageways that surrounded the central quadrangle, with the

13 James Grantham Turner, "'News from the New Exchange": Commodity, Erotic Fantasy and the Female Entrepreneur', in The Consumption of Culture 1600-1800: Image, Object, Text, ed. Ann Bermingham and John Brewer (Abingdon: Routledge, 1995), 419-39.

14 Deborah Simonton, "Sister to the Tailor": Guilds, Gender and the Needle Trades in Eighteenth-Century Europe', in Early Professional Women in Northern Europe, c. 1650-1850, ed. Johanna Ilmakunnas, Marjatta Rahikainen and Kirsi VainioKorhonen (Abingdon: Taylor \& Francis, 2017), 137-57; Elizabeth Sanderson, Women and Work in Eighteenth-Century Edinburgh (Basingstoke: Macmillan, 1996).

15 This neglect was first addressed by Jane Muncaster, "Six Foote of Shop Roome": Women as Subjects in the Records of the Royal Exchange in the 1690s' (MA thesis, Birkbeck: University of London, 2003). 


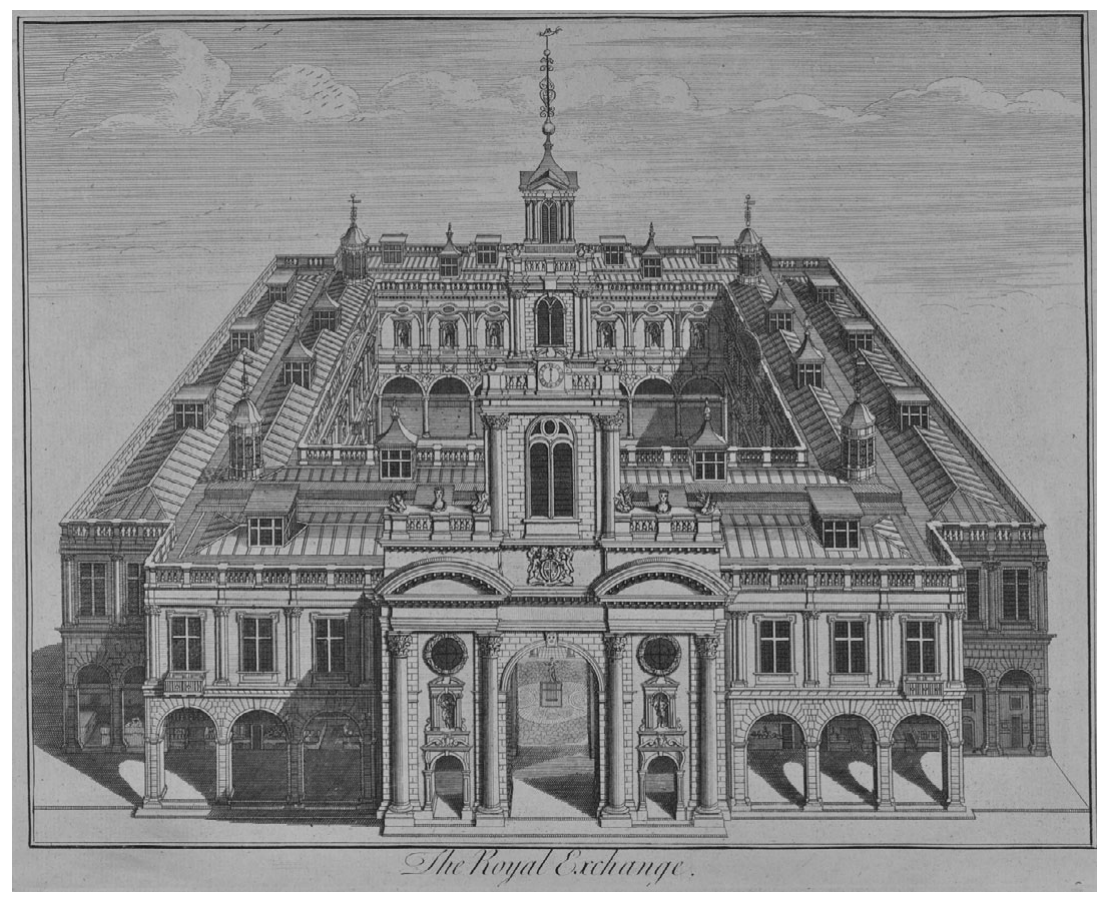

Figure 1.3 Robert White, The Royal Exchange (1671). $46 \times 57 \mathrm{~cm}$. The south portico with the chiming clock tower faces onto Cornhill. The upper pawn was on the top storey, lit by skylights.

London Metropolitan Archives (City of London).

idea that shoppers would walk the length of the circuit of shops. They were identified by the signs of animals or other names, such as the Orange Tree, the address given for the widowed seamstress Elizabeth Eardley when she took an apprentice in $1671 .{ }^{16}$ The layout encouraged browsing without commitment, as the shops were open, and goods could be seen when passing by (Figure 1.4). At the same time, the narrow walks and the small shops made for intimate encounters. The Exchange shops were tiny, measured before the Fire as 5 feet wide and $71 / 2$ feet deep, and not much larger afterwards, with 8 foot the standard width in 1670 . They were often leased in multiples, with tenants taking double shops, or a

${ }^{16}$ Michael Scott, ed., Apprenticeship Disputes in the Lord Mayor's Court of London, 1573-1723 (London: British Record Society, 2016); on the Exchange building, see Ann Saunders, ed., The Royal Exchange (London: London Topographical Society, 1997). 


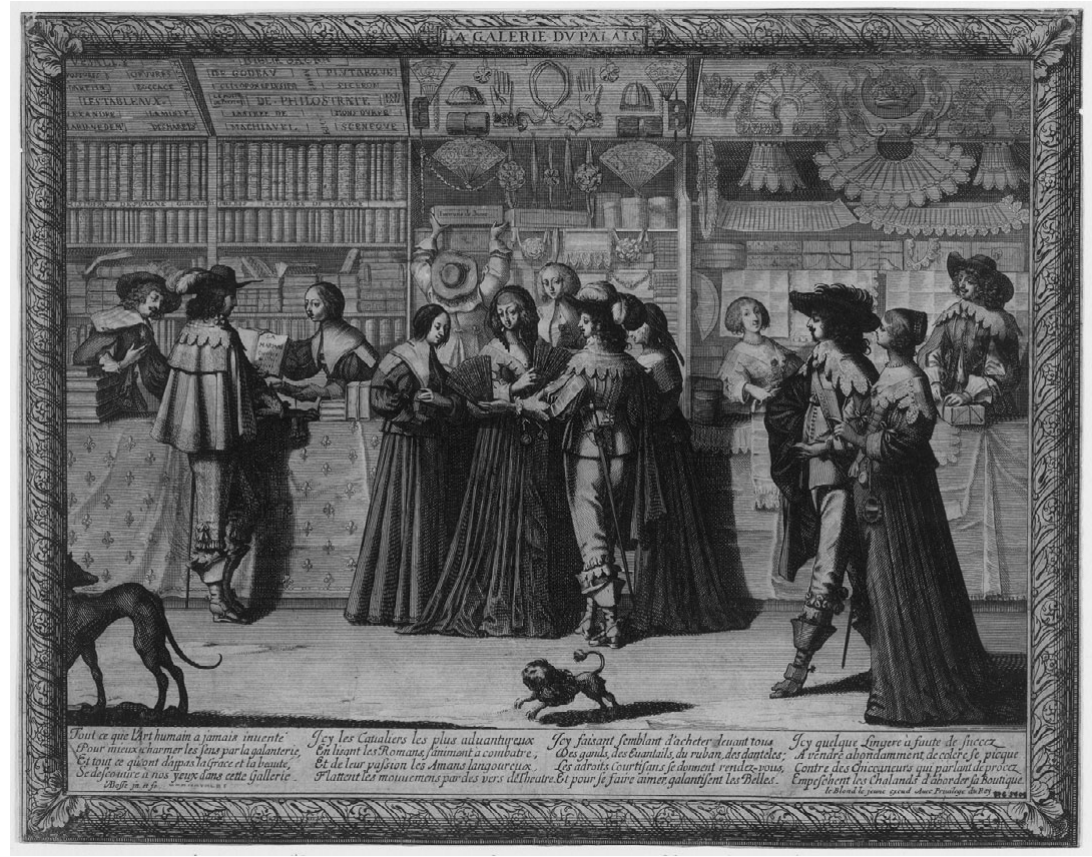

Figure 1.4 Abraham Bosse, La Galerie du Palais (1637-38). $25 \times 32 \mathrm{~cm}$. A Parisian counterpart to the Royal Exchange shopping galleries, showing collars, gloves and fans on sale as well as books. Musée Carnavalet (public domain).

shop and a half. ${ }^{17}$ Moveable partitions could be adjusted to suit shopkeepers' business; some deliberately encroached into the windows between the outer shops, blocking the light that showcased their neighbours' goods, or even cut into the Exchange walls to get more room. ${ }^{18}$ This versatility was, as Craig Spence has suggested, peculiarly suited to women's business. ${ }^{19}$ Jane Muncaster found that single women typically took smaller shops, though some continued with those same small spaces for years. Men also often took up small shops, perhaps as supplementary or initial enterprises. Widows and married women and men tended to

17 Ann Saunders, 'The Organisation of the Exchange', in Saunders, The Royal Exchange, 85-98.

18 Mercers' Company, Gresham Repertories (henceforth MC, GR) 1669-78, p. 230.

19 Craig Spence, London in the 1690s: A Social Atlas (London: Centre for Metropolitan History, 2000), 127. 
hold larger shops. ${ }^{20}$ Shopboards were provided to lock them up and to serve as counters for display and selling. Hanging signs before the Fire were replaced later with signs set into a frieze above the shops. In these narrow spaces, shopkeepers worked alone or in pairs, sometimes with an apprentice or servant, though some had enough room for a chair for a customer to sit on. Goods, customers and shopkeepers were pressed close together, and some shopkeepers in the later seventeenth century pressed for the stairways to be opened out and corner shops removed to make more spacious, handsome quadrangles. ${ }^{21}$

The emergence of consumer culture in the eighteenth century has been strongly identified with the performance of gender, with the retail sphere described as a female space, and shopping as an act of identity formation. As recent work has shown, shopping was hardly universally feminised. If plebeian and middling women were more likely than men to use the practical skills of assessing ripe food, the luxurious fantasies of clothes shopping were part of masculine as well as feminine leisure. The spaces of shopping likewise varied in their gender dimensions; the New Exchange's association with women sat alongside its grand spaciousness, while Westminster Hall's closeness to the political hub and law courts might give it a more masculine tone, but female and male shoppers used both. ${ }^{22}$ The Royal Exchange's unique location in the heart of the City gave it another character. Claire Walsh points out how effectively consumers extended the use of the galleries beyond their intended design, making them a place of social life. Shopping could be seen as a reflection less of individualistic identity than interpersonal activity, shaped by the perceived needs of others and the desire to impress and create narratives of self in a collective context; the social space of the Exchange loaded its transactions with social values and messages about status. ${ }^{23}$ Apprentices and mistresses were as significant as consumers in making these meanings.

The Exchange was also a place of rich literary fantasy. Like all urban spaces, its meaning was configured by the human relations that took place there, and those relations were also staged against the way it figured

20 Muncaster, "Six Foote of Shop Roome", 31-3. $\quad{ }^{21}$ MC, GR 1669-78, p. 120.

22 Claire Walsh, 'Shops, Shopping and the Art of Decision-Making in Eighteenth-Century England', in Gender, Taste, and Material Culture in Britain and North America, 1700-1830, ed. John Styles and Amanda Vickery (New Haven, CT: Yale Center for British Art, 2006), 151-77; Amanda Vickery, 'Women and the World of Goods: A Lancashire Consumer and Her Possessions, 1751-81', in Consumption and the World of Goods, ed. John Brewer and Roy Porter (London: Psychology Press, 1994), 274-303; Lorna Weatherill, 'A Possession of One's Own: Women and Consumer Behavior in England, 1660-1740', Fournal of British Studies 25, no. 2 (1986): 131-56.

23 Walsh, 'Social Meaning and Social Space'. 
in satire and cheap print. In the series of pamphlets lauding, and appealing to, the Royal Exchange, the figure of the female shopper was prominent. London's-Nonsuch; or, the Glory of the Royal Exchange depicted two sisters walking upstairs and downstairs, through hosiers and glovers' shops to those of goldsmiths and booksellers; it was presented as an advertisement of 'what Trades the Ladies and Gentelwomen may there finde'. ${ }^{24}$ Like most discussion of women in the Exchange, the text portrayed women as hunting not just for goods but for men. The coat-seller 'takes ladies by the waste'; the silk and prunella wool in the mercers' shops are sold by 'handsome fellows'. In the linen and lace shops, women are behind the counter, selling lace and bands and talking 'so wittily' to the men who come to see them that they 'allure / Their moneys from them, by their tongue'. As they turn to descend the stairs, the sisters praise the Gresham Committee for 'placing all the trades in view at once / So that we may not here and there Along the streets so wide / Run to and fro, for Trades, when here / We have them by our side'. Women's shopping, long established as integral to their domestic role as the spenders of what men gained, was easily read as gadding; the Exchange is imagined as a containing solution. Other texts made it sound more like a brothel, depicting the labour of shopping as sexualised exchange. Ned Ward's satirical romp through the Exchange buildings in 1699 presented the visitor as besieged first by 'swarthy buggerantoes' and 'bumfirking Italians' on the ground floor, then upstairs by the linensellers and milliners calling their custom into his ear. ${ }^{25}$ None of this was new; the sexualised critique of women's consumption had deep roots. ${ }^{26}$ The fantasy of flirtation ran parallel to the concrete exchange of material goods in the passageways of the Exchange, and in some cases, it actually interrupted women's labour. Women's work at the Exchange was not confined to its shops. The fruit sellers who worked at its doors were a perpetual focus of civic complaint in the sixteenth and seventeenth

${ }^{24}$ Ehver Kind, London's-Nonsuch; or, the Glory of the Royal Exchange (1668).

25 Ned Ward, The London Spy Compleat (1703), 66.

${ }^{26}$ On London's shops in this period, see Claire Walsh, 'Shopping in Early-Modern London c. 1660-1800' ( $\mathrm{PhD}$ dissertation, European University Institute, 2001); Vanessa Harding, 'Shops, Markets and Retailers in London's Cheapside, c. 1500-1700', in Buyers $\mathcal{E}$ Sellers: Retail Circuits and Practices in Medieval and Early Modern Europe, ed. Ilja van Damme et al. (Turnhout: Brepols, 2007), 155-70. On England, Hoh-cheung Mui and Lorna H. Mui, Shops and Shopkeeping in EighteenthCentury England (Montreal: McGill-Queen's University Press, 1989); Jon Stobart, Andrew Hann and Victoria Morgan, Spaces of Consumption: Leisure and Shopping in the English Town, c. 1680-1830 (London: Routledge, 2007). The intersection of sex and shopping is explored by Elizabeth Kowaleski-Wallace, Consuming Subjects: Women, Shopping, and Business in the Eighteenth Century (New York: Columbia University Press, 1997). 
centuries; the Exchange was a centre of the female-dominated world of street food selling. ${ }^{27}$

The Exchange, noted for the elegance of its shops, was also a place of bawdry. As a centre of information and advertisement, rude signs were hung up on its walls alongside the more prosaic notices; in 1660, Pepys heard of a picture hung up there of the naval officer John Lawson, who had cooperated with the Restoration of Charles II, with 'a great pair of buttocks shitting of a turd into Lawsons mouth, and over it was writ "The thanks of the House". ${ }^{28}$ Ned Ward described a rampant display of medical advertisements and crowds of hawkers selling glass eyes, ivory teeth and corn cures. ${ }^{29}$ These polar opposites of images of elegance and decay helped structure this space of fashion, playing into the tropes of deceit and cheating that were associated with consumption and providing the backdrop to the strenuous efforts at civility and gentility that were expected of mistresses and apprentices.

Twenty years after Hollar's print, the landscape it depicts was largely burnt to the ground by the Fire of 1666 . Most of the shops where City seamstresses and milliners worked were destroyed, along with the Exchange and its stalls; businesses relocated to the suburbs, and residents took refuge in the fields. The Fire's destruction of the Exchange had a symbolic power. To the clergyman Thomas Vincent, reflecting later on God's vengeance on the City, its fall heralded the final evacuation of citizens, their wives ('some from their childbed') and children. He saw the Exchange, 'the glory of the merchants, invaded with much violence; and when once the fire was entered, how quickly did it run round the galleries, filling them with flames; then descendeth the stairs, compasseth the walks, giving forth flaming volleys, and filled the court with sheets of fire'. ${ }^{30}$ The flames ran round the galleries just as the genteel shoppers had.

Women came to the fore of the Exchange when the post-Fire renovations shook up shop leases. In the short term, St Bartholomew's Hospital rehoused the tenants of shops on their City lands in the hospital cloisters; the Royal Exchange, which was not rebuilt until 1671, relocated to the Mercers' other principal building, Gresham College on Bishopsgate, and

${ }^{27}$ Laura Gowing, “"The Freedom of the Streets”: Women and Social Space, 1560-1640', in Londinopolis: Essays in the Cultural and Social History of Early Modern London, ed. Mark S. R. Jenner and Paul Griffiths (Manchester University Press, 2000), 130-53.

28 The Diary of Samuel Pepys: A New and Complete Transcription, ed. Robert Latham and William Matthews (London: Harper Collins, 1995), vol. I, 45; Lawson had previously been a republican.

${ }^{29}$ Ward, London Spy, 67.

30 Thomas Vincent, God's Terrible Voice in the City (1667), 61. 


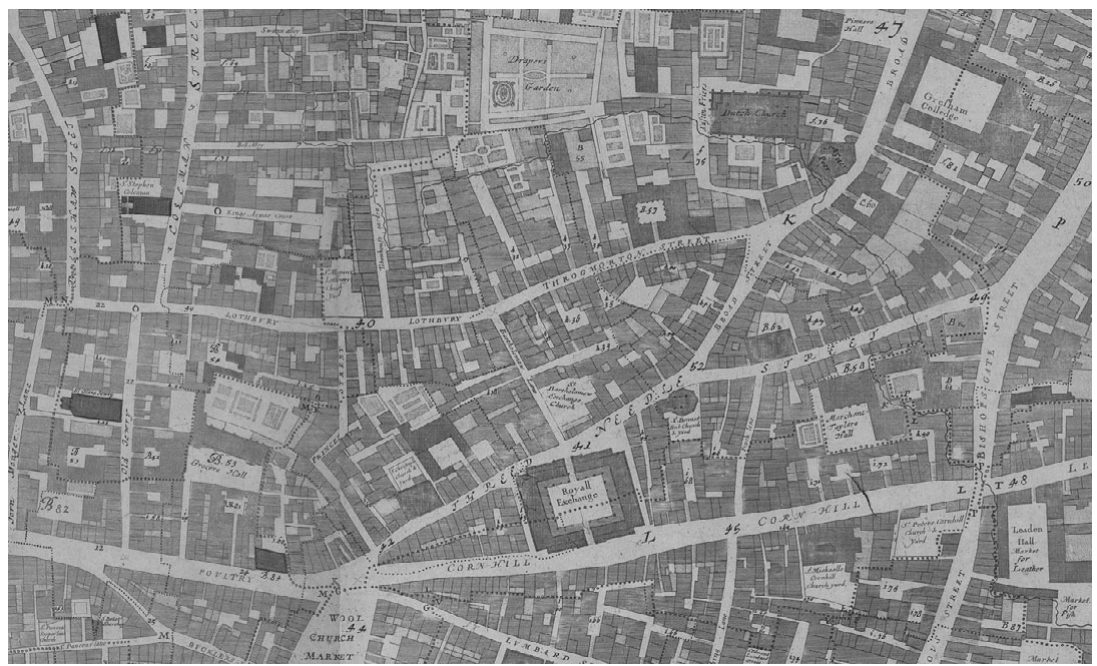

Figure 1.5 Detail of Ogilby and Morgan's 1676 map of London, showing the Royal Exchange (lower centre) and Gresham College (top right).

British Library (public domain).

leased space to shopholders there at reduced rents (Figure 1.5). Committee reports record a certain amount of chaos, as shops were crammed in alongside the meetings of the Royal Society and in the hayloft, cellar, quadrangle and galleries, with places accorded to people according to 'seniority' and a latrine built hastily when the nearby dunghill became 'noisome'. ${ }^{31}$ In the longer term, the City's efforts to encourage trade back in included offering the Freedom without charge to anyone taking a shop lease, and this may have encouraged women into the City's shops. ${ }^{32}$ Crisis, as at other moments, created opportunities for women.

The businesses rehoused in Gresham College already included some women. Anne Whitter, who had served an apprenticeship in the Merchant Taylors, was described as 'milliner de Gresham Colledg' when she took on her sister as an apprentice in $1670 .{ }^{33}$ Other women petitioned for places there on grounds of financial need. Widow Oliver was one: she had 'long kept a linen shop over against the Great Conduit in

31 Saunders, The Royal Exchange, 126.

32 J. R. Kellett, 'The Breakdown of Gild and Corporation Control over the Handicraft and Retail Trade in London', Economic History Review 10, no. 3 (1958): 381-94.

33 GL, MS 34038/16, 40. 
Cheapside and hath eight children'. ${ }^{34}$ As the new pawn was planned, women's past occupation of the Exchange gave them a claim to places in the new building. Mary Wimbush's request received favour, and the minutes recorded: 'Ordered that Mary Wimbush who was formerly bred in the Exchange be accommodated with a shop there and that her name be placed in shop next to Mrs Jane Kellway in the southwest corner'. There was apparently an actual paper plan on hand, and shortly afterwards Mary Wimbush's name was ordered to be erased again when the committee planned a large shop in the corner, with a promise 'to be preferred over any stranger'. ${ }^{35}$ To be 'bred in the Exchange' denoted a loyalty to which the management would attend, as well as a suggestion of training and perhaps a set of Exchange-specific manners and expertises.

The rebuilding project of the decade after the Fire created more open shops on Cheapside, encouraging a different mode of shopping. It also reconfigured the galleries of the Royal Exchange. One of the side effects was a noticeable increase in the number of women leaseholders. By the 1670s, when the Royal Exchange reopened for business, lease applications show that women held around half the stalls in the upper galleries and they continued to do so through the ups and downs of the Exchange in subsequent decades. Particularly in the City companies associated with the Exchange, the Haberdashers' and the Merchant Taylors', urban women used the Exchange to build their trades, and female apprentices worked with them. Tax and company records use 'exchangewoman' as an occupation, as for Elizabeth Hebborn, a maltster's daughter from Henley on Thames apprenticed to Winifred Cervington, 'exchangewoman' in the Drapers, in $1656 .{ }^{36}$

As the Exchange was rebuilt, applications began to come in for the new shops. The investment that citizens had in the building's shape and success is indicated by the extensive discussions, reverberating into print, over the post-Fire layout. A balance had to be struck between high numbers of shops to maximise rents and too much competition for existing trade, as well as cramped conditions for the shops. As the first floor was planned, the Gresham committee and representatives of the tenants discussed the relative merits of a 'double pawn' of many small shops, which, some argued, risked ruin and 'a Disreputacon upon the Place'. ${ }^{37}$ Henry Duke printed pamphlets arguing for a balance between a double pawn of smaller shops on two sides of the Exchange and deeper

\footnotetext{
34 MC, GR 1626-69, p. $249 . \quad 35$ MC, GR 1669-76, pp. 40-1. $\quad 36$ ROLLCO.

37 MC, GR 1626-69, p. 256; 1669-78, p. 1.
} 
shops with warehouses on the east and west. ${ }^{38}$ Duke was a shopkeeper himself and also the master of an apprentice who took up her own shop in the 1690s and continued it into the eighteenth century: Bethiah Paradise, from a wool draper's family in Devizes. ${ }^{39}$ In the end, the Gresham Committee settled for a double pawn all round, with the maximum number of small shops, which proved difficult to fill, particularly on the darker side. In 1712, there were 160 of them, but the land tax records of 1693 and 1703 show only around 50 tenants. The shops were laid out in two corridors, arranged around the quadrangle so as to feed visitors all the way around (Figure 1.6); the courtyard downstairs remained visible at the centre of the quadrangle of shops, with skylights above. Locations were described minutely as, for example, 'the western side of the south outward pawn'. Some shops were set into arches or by windows. The minutes of the Gresham committee show each part accruing its own reputation, relating particularly to its aspect, with its stallholders participating in the decision-making by means of representatives who were generally male. At one point, petitioners for changes to the layout were sent off to canvass the views of the other stallholders in their respective pawns. The 'innermost pawn', which had a view from balconies onto the trade in the quadrangle below, was the most popular, and the shops most expensive. The outermost pawn had windows but was felt to be short of light. In the southwest corner of the outer pawn in 1688, the roof was leaking, shops were suffering from 'dead trade' and being too far from the stairs. The East India Company's habit of sifting pepper by the cellar stairs annoyed the nearby tenants. ${ }^{40}$ Behind these negotiations was a network of businesswomen.

\section{Exchangewomen and Their Networks}

The management of shop leases at the Exchange shows women making their place in the passages of the upper pawn. Shopkeepers at the Exchange held long leases on their small shops, often subletting them to others. Before the Fire, women held a smaller proportion of leases than men, and many were subletting to others, often men; the shops were a useful source of income rather than employment. Increasingly, the committee took against this form of business and prioritised those who

${ }^{38}$ Kind, London's-Nonsuch; see also T. P., A Brief Memorial Wherein the Present Case of the Antient Leasees, the Inward Pawn Sub-Tenants, and the Outward Pawn Present Tenants, of the Royal Exchange [Is] ... Stated (1674).

39 LMA, COL/CHD/FR/02 138/78; LMA, MS 11316/13 (1703).

${ }^{40}$ MC, GR 1626-69, p. 216. 


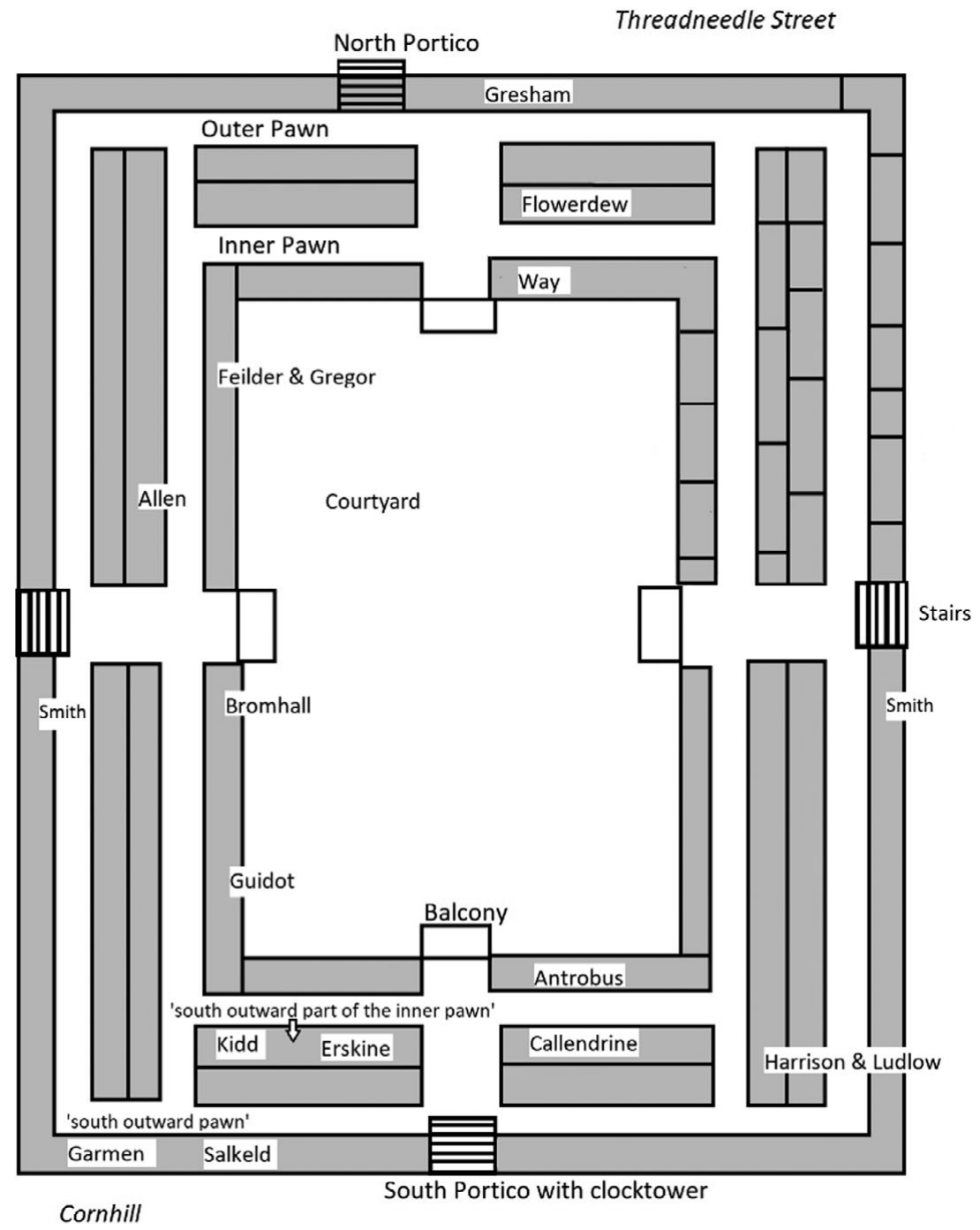

Figure 1.6 Schematic plan of the layout of the first floor of the Royal Exchange after the Fire. Tenants from the 1680s and 1690s. Based on information in Gresham Repertories.

would occupy the shops themselves. The last petitions heard by the Gresham Committee before the Fire raised this issue. Mary Newton, née Hunt, came to request leases for two shops on the south side of the Exchange known by the signs of 'The Ring-Dove' and 'The Griffin', 
which had previously been held by her father, a mercer; the estates he had left his children had suffered confiscations at the Restoration. Mary pleaded that her husband had lost thousands of pounds and that she had 'nine children whose daily bread is uncertaine'. However, the shops were claimed by one of her brothers too, who had worked there as an apprentice, and by the two men presently running them, who had 'drawn their trades' into the shops. The committee determined to prioritise those in occupation and referred Mary Newton instead to 'the Charity of the City and Company'. This resolution that 'none should have the shops but those who would occupy the same in their own persons' suggests an approach that might have helped prompt women into occupying shops themselves as well as taking up leases. Mary's own story reveals some of the ways a woman might fit into the patrimonial structure of company and family. The Mercers' records indicate that Richard Hunt's eldest son, John, took up his freedom by patrimony and used that to apprentice his younger brother, Benjamin. Mary's husband, Henry Newton, another Mercer's son, was another of Richard's apprentices, and he later became the master of Mary Hunt's younger brother, Nathaniel. The two families, by 1666, were woven together by the ties of apprenticeship and marriage. They were also scholars: another brother, Richard, was appointed the Gresham Professor of Rhetoric. Mary's eldest son, Henry, at Oxford at the time of her petition, became a diplomat, and when a German professor later recounted Henry Newton's life, he described Mary Newton as 'distinguished amongst her sex for her remarkable understanding': his Latin word prudentia suggests practical foresight. ${ }^{41}$ Mary died in 1714 , requesting to be buried in the Mercers' Chapel as her brothers and father had been: the company ties remained strong. The Mercers were an exceptionally rich and influential company, but the patterns that wove kinship into business, with women as linchpins, were not unusual as Richard Grassby's meticulous unravelling of the family ties of seventeenth-century businesses has shown. ${ }^{42}$ In this politically and academically inclined family, both sons and daughters expected to have a stake in the Exchange, if not a shop of their own. The business family, Grassby argues, had an economic identity of its own, and every business had a familial structure. In families like these,

${ }^{41}$ Stuart Handley, 'Newton, Sir Henry (1650-1715)', Oxford Dictionary of National Biography, www.oxforddnb.com (2008); John Ward, The Lives of the Professors of Gresham College (1740), 319; Georg Christian Gebauer, Narration de Henrico Brenkman ... et vita Henrici Newtoni (Gottingen, 1764), 216, whose Latin phrase is 'matronam ob insignem prudentiam inter alias sui sexus eminentem'.

42 Richard Grassby, Kinship and Capitalism: Marriage, Family, and Business in the EnglishSpeaking World, 1580-1740 (Cambridge University Press, 2001), 413. 
the world of the narrow shops was connected through inheritance, investment and sales to the expanding empire. It sat above a quadrangle in which traders apparently clustered by nationality, a microcosm of the global economy. Contemporary prints represent Ottoman Turkish merchants in traditional dress squatting round the outside, alongside many other nationalities. ${ }^{43}$ The gentry origins and family wealth of many of the women Exchange shopkeepers rooted them firmly in London's growing global market. Women's part in the financial revolution of the late seventeenth century is increasingly well documented: they invested in government stocks, which could escape the rules of coverture, and had long been invested in the Virginia and East India Companies. Women with property were expected to defend familial and personal interests, often through petitions and legal actions. ${ }^{44}$

In the years before the Fire, twice as many men as women were requesting leases, but the shops may well have included more women trading: an increase in women traders was noted in the 1640 s, a time at which companies were also beginning to see female apprentices. ${ }^{45}$ When the shops were reallocated after the Fire, both women and men applied for them, but the male applicants were more likely to have a history in the Exchange. In 1670 , rights to the new leases were allotted first to those who formerly kept shop in the old Exchange, in the order of 'seniority'; the rest, from the time they respectively had the right to the Freedom of the City. ${ }^{46}$ This may have kept new unfree women out, but in fact there was only a short period in which there were no vacancies, and, by the 1680 s, the more significant issue was the quality of shops in use. Men continued to outnumber women in the leases overall after the Fire, but in the upper pawn, as opposed to the downstairs shops, the gender ratio was close to equal. This balance laid the foundations for the roughly 50:50 ratio of men and women in the upperpawn shops of the late seventeenth century. ${ }^{47}$

43 Wenceslaus Hollar, 'The Royal Exchange' (1644).

44 Barbara Todd, 'Fiscal Citizens: Female Investors in Public Finance before the South Sea Bubble', in Challenging Orthodoxies: The Social and Cultural Worlds of Early Modern Women: Essays Presented to Hilda L. Smith, ed. Sigrun Haude and Melinda S. Zook (London: Ashgate, 2014), 53-74; Misha Ewen, 'Women Investors and the Virginia Company in the Early Seventeenth Century', Historical fournal 62, no. 4 (2019): 853-74; Pamela Sharpe, 'Gender at Sea: Women and the East India Company in Seventeenth-Century London', in Women, Work and Wages in England, 1600-1850, ed. K. D. M. Snell, Penelope Lane and Neil Raven (Woodbridge: Boydell \& Brewer, 2004), 47-67.

45 Saunders, The Royal Exchange. $\quad{ }^{46}$ MC, GR 1669-76, p. 36.

47 The fullest list of leases is in LMA, CLA/062/04/16. Another record of inhabitants of shops (not all of whom were necessarily the leaseholders) is in the Land Tax records of 1693 and 1703. 
Since leases were often granted to those already in occupation as subtenants, this change may not represent a dramatic increase of women in the shops, but it does reflect a formal recognition of women as shopkeepers of permanence and substance. At the same time, numbers of female apprentices in guilds were steadily increasing from 1667. Some of them actually joined mistresses working in the Exchange, like Elizabeth Parker, a London merchant tailor's daughter apprenticed in 1677 to Elizabeth Deadman, a widow in the Haberdashers working in the east side of the Exchange, but more broadly they were part of an environment in which more daughters of artisans and gentry were moving into the clothes trade. ${ }^{48}$ Alongside those who came in from apprenticeship were widows carrying on a shop trade, or starting a new one, and married women running independent shops. The widespread use of 'Mrs' [mistress] to denote a businesswoman makes it hard to determine marital status, though research into the female tenants of the late seventeenth century indicates a high proportion of single women and widows. ${ }^{49}$

The first woman recorded as receiving a lease after the Fire was Elizabeth Athey, a widowed periwig-maker, who, in June 1670, was given a 10-foot shop downstairs, on the easterly side under the north portico, to hold for eleven years for $£ 30 .^{50}$ On 13 August 1670, when Mary Wimbish along with Mr Debnam, Mr Hudson, Mrs Lloyd and $\mathrm{Mr}$ Dudley all requested shops in the new pawn, they were told that they would be granted shops 'in case there happen to be surplusage of shop room above that will satisfie those bred in the Exchange'. Mary Lloyd, who lived on Little Tower Hill, had already asked in April and had been told that the committee doubted they would have a surplus; she was still asking in October, by which time she was promised first choice. ${ }^{51}$ Records of another 'ancient' leaseholder, Alice Salkeld, reveal the way credit and favour operated in shop allocations over a period when the popularity of exchange shops was very variable. Salkeld complained in October 1670 that Hester Sheppard, 'a stranger there', had been given the choice of a shop before her. The committee accepted her point and ordered that Sheppard's name be removed from the shop on the south side where she had been placed, Salkeld's put there instead and Sheppard reallocated to Salkeld's inferior position. In 1671, Salkeld was told, with two other women, 'to expect the favour of the

48 Scott, Apprenticeship Disputes.

49 Muncaster, "'Six Foote of Shop Roome"'. On the meaning of 'Mrs', see Amy Louise Erickson, 'Mistresses and Marriage: Or, a Short History of the Mrs', History Workshop fournal 78 (2014): 39-57.

50 MC, GR 1669-76, p. 14. $\quad{ }^{51}$ MC, GR 1669-76, pp. 11, 28, 32. 
Committee, in regard they have remained in the pawn when others deserted it'. ${ }^{52}$ In January 1673, she echoed the complaint of Sarah Garmen, a Merchant Taylor with a small shop at the sign of 'the Nun' at the end of the south outer pawn 'next the staircase going up to the leads', who had requested an abatement of rent because the workmen on the roof had made so much dust that 'it hath spoiled her commodities' and kept away her customers. A great part of her stall, too, had been cut away to widen the passage; her rent was reduced accordingly to $£ 195 \mathrm{~s}$ a year for an area of 7 feet. ${ }^{53}$ Salkeld still held a shop in the south outward pawn in the 1680s, by which time she was complaining again that her shop was a foot and a half less than what she paid for, that it was darkened by the tower and that the whole situation was 'cold'. The committee viewed it but decided, this time, that her complaints were groundless. ${ }^{54}$ In this period of adjustment, women's shops look rather more likely to have been exchanged or withdrawn to convenience the committee and other leaseholders, or the general interest of the Exchange. Mrs Hardcastle requested to have her rent lowered on the basis that she had given up her shop to accommodate 'another person who otherwise would have bin troublesome to the City and Company', though her claim was rejected on the basis that 'it might be a means of unsettling the whole Exchange'. ${ }^{55}$ The balance between perceptions of equity and the utility of privilege was important and inflected by gender. The notion of accommodation, something apparently more likely to be expected of women, gave them both a weapon and a weakness. Credit was part of shopping, but also integral to the operation of the Exchange itself, the distribution of leases and favoured places: credit was, as recent work has stressed, central to early modern culture as well as to economies, a practice of work as well as a world view and one in which gender was a critical vector. ${ }^{56}$

Married women's subordinate legal position, as Craig Muldrew has pointed out, posed a problem for credit in an economy built on verbal promises. ${ }^{57}$ Marital status played a relatively minor role in the negotiations for shops, and unlike other records, those of the Exchange records do not always subsume married women under their husbands' names. The custom of 'feme sole trader status', which enabled London's

52 MC, GR 1669-76, p. $73 . \quad{ }^{53}$ MC, GR 1669-76, p. 111-12; GL, MS 34042, p. 38.

54 MC, GR 1676-82, p. $216 . \quad{ }^{55}$ MC, GR 1669-77, p. 71.

56 Clare Haru Crowston, Credit, Fashion, Sex: Economies of Regard in Old Regime France (Durham, NC: Duke University Press, 2013); Julie Hardwick, 'Gender, Credit and Rethinking (Economic) History', History Workshop fournal 81 (2016): 253-60; Muldrew, “"A Mutual Assent of Her Mind”?', 47-71.

57 Muldrew, "'A Mutual Assent of Her Mind"?? 
married women to trade and engage in contracts and debts as if they were not bound by coverture, was clearly live in the Exchange, evidenced by the way the 'exchange-woman' was invoked as an example of female business. Sometimes, though, there is evidence of the complexity of married women's situation in regards to making contracts and particularly in relation to the Gresham Committee, husbands spoke for or with married women in business affairs. The records are precise about the degree to which husbands' and wives' interests and responsibilities were shared or separate. Mrs Hamond, summoned in 1626 to explain the rent she owed on a shop she occupied, was 'respited to speak with her husband' before she gave the Chamberlain an answer. ${ }^{58}$ Two male stallholders of the $1670 \mathrm{~s}$ took advantage of their wives' previous Exchange history. Mr Marshall and Mr Egleston, in arrears in their rent, pointed out to the committee that each of them had a wife who had already paid for her own shop 'in their maiden condition'; they had married before they took up the leases. After some discussion, the money was refunded to the men on condition they cleared their own arrears. ${ }^{59}$

A high rate of widowing and remarrying complicated Exchange arrangements. Wives' inherited leases did not pass automatically to husbands: Katherine Allen petitioned in 1636 for the shop and a half granted to her deceased husband to be transferred to her new one. ${ }^{60}$ After she was widowed in about 1648, Hester Potts took over the lease of her deceased husband's shop on the west side of the Exchange, refusing a few years later to exchange it for two shops on the inferior northern side. ${ }^{61}$ Like most City companies, the Gresham Committee dealt constantly with deprived widows in its charitable endeavours, and occasionally the two combined. Although the Committee refused Mary Southaike's pleas to reduce the fines she was due to pay for transferring shop leases in 1654, to avoid making a precedent, they returned most of them back to her 'in regard she hath a charge of children' ${ }^{62}$ It was a neat illustration of the balance between treating widows equivalently to men in business and recognising them as objects of charity.

Royal Exchange shops became part of the transactions of family inheritance. Luke Cropley came to ask for a shop in 1668 for his attorney's business; he had married 'the widow of $\mathrm{Mr}$ Thomas Bland scrivener', who had 'a little shop on the Northside' with two years left on the lease but wanted a shop of his own. This was Mary Bland's third marriage, and she had sold land from her first marriage to her second husband. Her

58 MC, GR 1626-69, p. 8.

59 MC, GR 1678-1722, p. 16.

60 MC, GR 1626-69, p. 44.

61 MC, GR 1626-69, pp. 121, 136.

62 MC, GR 1626-69, p. 144. 
little shop in the Exchange was part of a transatlantic estate, which, by the time of her son's death, also included at least two slaves, named in his will. ${ }^{63}$ Jane Clarke surrendered all her leases after the Fire but maintained a right in the Exchange, the committee promising that her relative would have preferential right to a place near his previous occupancy. Elizabeth Eardley enterprisingly took over her bankrupt brother's shop in the Exchange in 1668, before the new building was ready; she planned to install her sister in it to dispose of his goods. Her husband Richard's inventory indicates that before his death in 1663, they had run a shop dealing in children's clothes, laces and ribbons; perhaps she continued it afterwards and expanded into the Exchange. By 1670, she was holding a shop in her own name in the rebuilt Exchange. Her deceased husband's freedom of the Haberdashers enabled her to take on a company apprentice for a few years, but the contract broke down, and by 1682 Eardley was 'broke and gone'. ${ }^{64}$

As prominent as marital ties were those between other family members, particularly sisters and mothers and daughters. As in apprenticeship arrangements, kinship ties between women helped promote them into desirable shop places. In 1670, Mary Hebb, who leased a window shop on the east side of the inner pawn, came to ask if the committee would accommodate her daughter with a shop on the south side of the outward pawn; the committee agreed, because she was already short of shop space. Susanna and Rebecca Way, described as spinster sisters, took over a shop and a quarter in 1679 on the north inner pawn, promising to pay $£ 7$ next Michaelmas. Rebecca was a member of the Salters' Company, probably by patrimonial right; she is cited on the back of another woman's freedom in the Barber-Surgeons' in $1690 .{ }^{65} \mathrm{Naomi}$ Slany, a widow $£ 30$ in arrears in the ill-fated east outward pawn, had so many losses that she could not keep her shop, but her daughter came to pay her last quarter's rent before she left, and she was discharged $£ 30$ of arrears. The widowed Alice Guidot held a 10-foot shop in the inner pawn with the merchant Joseph Alder, her son-in-law; her father and son also had shops. ${ }^{66}$ Other shops were passed between friends or trading connections. Katherine and Herbert Allen held a shop 'at the sign of the

${ }^{63}$ John Frederick Dorman, ed., Genealogies of Virginia Families: From Tyler's Quarterly Historical and Genealogical Magazine, vol. 1 (Baltimore: Genealogical Publishing Co., 1981), 542-3; John Bennett Boddie, Seventeenth Century Isle of Wight County, Virginia (Baltimore: Genealogical Publishing Co., 1973), 681.

${ }^{64}$ MC, GR 1678-1722, pp. 82, 99; LMA, CLA/002/02/01/0276, f. $24 \mathrm{~b}$.

${ }^{65} \mathrm{LMA}, \mathrm{COL} / \mathrm{CHD} / \mathrm{FR} / 02 / 0036$, no. 52; MC, GR 1678-1722, p. 16.

${ }^{66}$ LMA, P69/MRY7/A/002/MS04997 (10 December 1681), Joseph Alder/Margaret Guidott; MC, GR 1678-1722, p. 210. 
Parrot', on the west side, in the 1660s. Herbert died while the Exchange was closed after the Fire, and Katherine re-opened it when the pawn was rebuilt, trading until 1690 when she passed on her 8 foot of shop room to William Barton and his wife, Mary, a milliner. ${ }^{67}$ Both Katherine and Mary had been pursued in the Mayor's Court by their recalcitrant apprentices. Bonds between women, as Amy Froide has shown with respect to single women's wills, were critical to women's economic independence. ${ }^{68}$

Despite the apparent demand for leases, some parts of the new Exchange seem never to have become successfully established. The outward pawn was particularly problematic, without benefit of the light and activity of the courtyard below. Mr and Mrs Smith, linen-sellers who had taken out leases for shops in both the west and east outward pawns, found they could not find tenants for them and so were released from their obligations. The south outward pawn was still unbuilt when tenants were moving back into the rest of the building, and those who had been given leases there found they still had no functioning shops. Mary Browne was one of them: she petitioned in 1679 that she had been persuaded, 'for the service of the City', to exchange her lease of a valuable shop in the inner pawn for a larger one in the south outward pawn. Those shops, she said, remained 'wholly desolate ... for the most part'. ${ }^{69}$ The committee reduced her arrears from $£ 71$ to $£ 22$ to represent the lesser value of her new position.

By 1682, several female tenants were described as in 'desperate arrears'. Requests for abatement included one from Mrs Hoard, a married woman with 'many children' who complained that 'trading hath been and still continues very low'; she was still in arrears in $1687 .{ }^{70}$ Mary Goddard was let off the rent for her shop as she had left it when the shops 'went to ruin', though Elizabeth Goddard continued paying for her 9 foot of shop room in the inner pawn, at $£ 22$ for two years. In at least some parts of the building, the leases' costs were too heavy for the shops' profits. In 1684, 'the widow Miles' countered a demand for her $£ 26$ arrears with a plea that she had paid $£ 5$ for a shop she had never had and another $£ 6$ towards the general rebuilding; the committee reached a compromise with her. Elizabeth Foster refused to pay her quarter's rent because she had left her shop, and her husband was in debt. At the same time, though, the court continued to charge extremely highly for leases,

${ }^{67}$ MC, GR 1678-1722, p. 222.

68 Amy M. Froide, Never Married: Singlewomen in Early Modern England (Oxford University Press, 2005).

69 MC, GR 1669-77, p. 153. $\quad{ }^{70}$ MC, GR 1678-1722, pp. 20, 172. 
even in the unpopular areas: Elizabeth Harrison, citizen and joiner, paid $£ 25$ for a year's rent of 10 foot of shop room in the east outer pawn in 1687 - half the average house rent in Cornhill. ${ }^{71}$ Other shops in the City rented for an average of only $£ 9$ a year. ${ }^{72}$ Petitions in 1688 crystallised the complaints of the outward pawn shopkeepers: deadness of trade, distance and narrowness of the passage from the stairs to the shops; annoyance from the workmen repairing the roof; and shops standing empty to the 'great discouragement of the place which daily grows worse'. ${ }^{73}$ High rents and lease premiums marked the place's continuing prestige, whilst gathering arrears made it possible for businesswomen to continue in the face of failing trade or low profits.

Who were the exchangewomen? Both 'exchangewoman' and 'exchangeman' were occupational titles, given in tax listings in the 1690 s, but many of those who were listed that way have left no other record in the accounts of the Exchange itself. Those who worked on the stalls were not always the leaseholders. But enough survives to suggest an emerging profile of exchangewomen with distinctive social, domestic and economic features.

Those who leave the best evidence are connected to gentry and merchant families; they were the likeliest to be able to make the substantial investment in leases, and apprenticeship and freedom to a guaranteed trade could be an inheritance in itself. Some were from London families. Anne Gosfreight, whose name is in the 1702 list of stallholders, was the daughter of longstanding stallholder Solomon Gosfreight. Her father had left her a half-share of his estate in 1700, having, as his will explained, already advanced her brother and one of her sisters; another sister had forfeited her inheritance by joining a Benedictine convent in Paris, from where she petitioned the queen for the protection of her brother as a merchant banker in Alicante. ${ }^{74}$ Lucy Maes, one of the many apprentices of John and Frances Spillett, was the daughter of a gentleman from St Andrew Holborn. At his death in 1682, his estate was divided between his wife and three daughters. The eldest, Mary, received a pearl necklace and $£ 40$ extra as well; Lucy, the youngest, was apprenticed to the Spilletts and became free in 1692. In another case, apprenticeship in the Exchange, like the removal of fines, was offered as charity to a needy woman. Margaret Lendale, the daughter of a captain, received royal charity to set up as an apprentice specifically in the Exchange, indicating its status as a reliable career for girls. First she was apprenticed to a

\footnotetext{
71 MC, GR 1678-1722, p. $185 . \quad 72$ Spence, London in the 1690s, 125, 176.

73 MC, GR 1678-1722, p. 189.

74 Calendar of the Stuart Papers (London: HMSO, 1902), 181.
} 
haberdasher in the Royal Exchange in 1660, her premium paid by royal gift. When her time ran out, she petitioned, pleading that 'the said Trade being to Sell all Sorts of Rich Laces and other things of great value requireing a Considerable Stock; for want thereof, yor Petitioner (who is destitute of Friends and all other meanes of subsistance) can not sett up ye same, without yor Majesties Espetiall Grace and favor be further extended'. She received $£ 200$ in royal bounty to set up her shop. ${ }^{75}$ Other apprentices came from provincial gentry or mercantile families, often with London connections. Rowley Grevill, who held three quarters of a shop in the 1690s, inherited the estate of her namesake, a spinster aunt. Both of them had been christened Raleigh Grevill; the elder was the daughter of Richard Grevill, a cousin of the poet Fulke Grevill, who christened his children Fulke and Raleigh in memory of his friendship with Walter Raleigh. London made them into Rowley or Rawley, the name given in the Exchange records and both their wills. ${ }^{76}$

Exchangewomen were meant to be free of the City in order to trade there, and many of them had the freedom in their own right or through their husbands or fathers. Unlike men, they were rarely described as citizens. Rather, the phrase 'of London' was used to indicate the freedom. Ann Gregor had been a gentry apprentice from Cornwall: once free, she took an Exchange shop and became in the Gresham records 'spinster of London'. ${ }^{77}$ Elizabeth Harrison was unusual in claiming, or being given, the title 'citizen and joiner', yet plenty of exchangewomen had the freedom after apprenticeship. Agnes Blennerhassett's short Exchange career exemplifies one route. Apprenticed in 1686 to John and Frances Spillett, who had two shops in the upper pawn, she became free in 1692 and took out a lease of her own, giving her 8 feet of shop room on the 'inner part of the east inner pawn', previously held by Mrs Clarke, for eleven years at $£ 20$ a quarter. She held the shop until the end of 1695 , when she married a goldsmith. ${ }^{78}$ Several freewomen took their sisters into apprenticeship and, presumably, into their Exchange shops. Sarah Bonwick, who ended up in arrears in the 1680s, had been apprenticed in 1669 and become free of the Drapers' Company in 1676. She took her sister Mary as an apprentice in $1680 .{ }^{79}$ Sarah's path of freedom

LMA, CLC/L/HA/C/011/MS 15860/006, 84; TNA, SP 29/281A f. 84; Calendar of Treasury Books, vol. 2, 1667-1668, ed. William A. Shaw (London: HMSO, 1905), 605.

76 TNA, PROB 11/384/256; GL, MS 9172/102, no. 247.

${ }_{77}$ Muncaster, "Six Feet of Shop Room"'.

78 GR 1678-1722, p. 278; England, Essex Parish Registers, 1538-1900 (Salt Lake City, UT: FamilySearch, 2013); Ambrose Heal, The London Goldsmiths (Cambridge University Press, 1935), 89.

79 ROLLCO (Sarah Bonwick). 
before shopkeeping was not universal; other exchangewomen seem to have become free after they had begun trading, which may suggest some pressure was applied.

The fullest information about an exchangewoman we have, though, comes from Hester Pinney, a lace seller from Bristol who worked with her sister in the New Exchange on the south side of the Strand just below Covent Garden. As Pamela Sharpe has shown, the Pinney women and particularly Hester built an independent working life from the family lace trade, drawing on connections that came from family ties and their own enterprise. ${ }^{80}$ Letters to Hester show her lodging in various places, including with Mrs Janeway, for which she records paying $£ 810$ s a year. Others were addressed to her at 'the Seven Stars in the inner row below stayres of the New Exchange in the Strand', or 'Mr Carr's against the Rose Coffee House in Covent Garden', and sometimes in taverns, where she also met other tradeswomen and later conducted her administrative and financial business. ${ }^{81}$ In 1687, her father, an ejected Presbyterian minister, was writing to her from Dublin, asking querulously 'to what purpose you would furnish a room in London, where you have no business I do not at all understand'. Hester's mother refused to send her a bed, since they did not want her to live there. Two months later, John Pinney wrote again to say he was 'not satisfied with your living in a taverne a place of so many temptations and dangers', urging her to return to live with him: 'if debts remain let your sister get them in \& be accountable to you for them ${ }^{82}$ Hester spent most of the rest of her life in London, moving from her Exchange work into managing investments and maintaining amicable, amatory and professional relations with gentlemen and merchants.

The take-up of shops by recently freed gentry apprentices like Ann Gregor from Cornwall and Bridget Flowerdew from Norfolk suggests that as well as having, probably, substantial premiums to start off their apprenticeships, they were also able to command the money to begin and continue leases: Bridget Flowerdew began an eleven-year lease in 1690, in a shop she was already occupying, paying an $£ 18$ fine and $£ 18$ a quarter. Bridget had been apprenticed to Ann Flowerdew, probably her aunt, in 1679, became free ten years later and was still taking apprentices

80 Pamela Sharpe, 'Dealing with Love: The Ambiguous Independence of the Single Woman in Early Modern England', Gender E History 11, no. 2 (1999): 209-32; on Pinney as investor, see Amy M. Froide, Silent Partners: Women as Public Investors during Britain's Financial Revolution, 1690-1750 (Oxford University Press, 2016), 186-95.

81 Bristol University Special Collections, Pinney Papers.

82 Geoffrey Nuttall, ed., Letters of Fohn Pinney, 1679-1699 (Oxford University Press, 1939), 51. 
in $1711 .^{83}$ Other women seem to have used taking apprentices as a means to establish those expensive shops. The high premiums paid by some gentry apprentices reversed the usual economics of apprenticeship: in cases like Ann Gray's, the relationship began with an apprentice putting in a premium that far exceeded the cost of their training or keep, enabling their mistress to establish herself in a prestigious location with a good display of goods. The gains were not just the skills of sewing and selling but the credit that was provided by experience in a city shop with the shelter of a mistress's household; clothes came into the bargain too. When Gray sued for the return of her $£ 40$ premium after two years, she got back $£ 30$ of it: her witnesses had argued both that she had not acquired the requisite skills but that the $£ 24$ worth of clothes provided by her friends had been 'for the most part worne out and spoyled'. ${ }^{84}$

The shops of the pawn worked well for women because they were flexible and small, but also, it seems, because over the years, a special set of customs had evolved to suit its apprentices. The Exchange was treated as a place with its own rules. No paperwork laid these down, but a number of references in both legal cases and petitions make clear that by the later seventeenth century, 'exchange-maids' expected a particular, abbreviated apprenticeship, for fewer years (typically five, rather than the standard seven) and higher premiums (as high as £50). Katherine and Herbert Allen, whose several apprentices worked in their Exchange shop, regularly bound their female apprentices for five years. When one of their apprentices went to court, bringing the contract into question, Francis Hunlock testified in support of Katherine Allen that it is usuall with persons keeping shopps in the Royall exchange London to take maiden apprentices for noe longer time then 5 yeares' and also 'it is not usuall with persons keeping shopps in the exchang to find or provide their mayden Apprentices with any manner of apparell or necessaries of that kinde but that ye same are usualy provided \& given unto them by their frends during their Apprenticeship there' ${ }^{85}$ Exchange-maids followed their own rules. Whether intentionally or not, this meant that those who graduated from these contracts were not entitled to be free, because they had not served the seven-year term that custom required: one of them, Hester Wright, kept her shop in her brother's name for this reason. ${ }^{86}$

${ }^{83} \mathrm{MC}$, GR 1678-1722, p. 205; LMA, COL/CHD/FR/02/24, nos. 46, 146; COL/CHD/ FR/02/0171, no. 34; COL/CHD/FR/02/0394, no. 9 (Flowerdew, Hall, Stamper).

${ }^{84}$ Patrick Wallis, 'Apprenticeship and Training in Premodern England', fournal of Economic History 68, no. 3 (2008): 832-61, where the 'standard account of apprenticeship' diagram is reproduced. Gray's case is LMA CLA/024/05/493.

${ }^{85}$ LMA, CLA/024/05/131B (1662). ${ }^{86}$ LMA, CLA/024/05/131B (1662). 
Francis Hunlock's testimony reflected an Exchange expertise, which he shared with his female relatives. A wealthy Painter-Stainer, he had a shop in the Exchange from at least 1668. His wife, Martha Osbaldeston, had inherited from her father, when she was twenty-five, a shop lease at 'Britain's Burse', the New Exchange in the Strand, which was temporarily sublet to another woman. Her sisters and sisters-in-law inherited books, but Martha was the only one still single when her father made the will, and a shop was a flexible, useful inheritance. ${ }^{87}$ After her husband Francis's death in 1679, Martha took up a lease of her own in the Royal Exchange. She took at least one girl as an apprentice milliner, in 1687. She still held the shop in 1690, when she died in Clapham, and she bequeathed it to another widow who lived near the Exchange: Mary Stalman, who was taxed at $£ 25$ in 1692 for 'all her houses in Maidenhead Court and Grubb Street', at the heart of the cheap print trade. ${ }^{88}$ Both their wills offer glimpses of wealthy women working and planning in the late seventeenth-century city. Martha Hunlock, with several surviving adult children, one of whom had moved to New England, left careful sums to each of them, many derived from existing loans to the children or from goods of hers that were already in their possession. That she left the shop away from them might indicate that she did not expect, or trust, them to use it, or that her bond of friendship or business with Mary Stalman took priority. In fact, the bequest to Mary Stalman seems to have fallen away, for, a year later, the Gresham Committee were discussing the Hunlock children's request to use the shop, which had earlier been sublet to another tenant, themselves. Mary Stalman, the intended inheritor of the Hunlock shop, also left a revealing will. Widowed with three children in 1679, her will in 1696 mentioned none of them but instead left her estate to the under-age daughter of another woman with no evident ties of kinship. The bequest included those standbys of late seventeenth-century widows, an Exchequer tally (an interest-bearing loan) which paid $£_{1} 14$ a year for ninety-six years, and six lottery tickets which paid a minimum of 26 s each for sixteen years. ${ }^{89}$

Within the Exchange, a web of connections sustained the trading community, many of them between spinsters and widows living and working together. The list of tenants in the Land Tax of 1693, of whom half were women, records a series of traders who were connected by

${ }^{87}$ Henry F. Waters, Genealogical Gleanings in England (Boston: New England Historic Genealogical Society, 1901), part 2, 1043-5.

${ }^{88}$ Scott, Apprenticeship Disputes. The apprentice, Sarah Wavell, sued for the return of her premium after Martha's death. MC, GR 1669-76, p. 82; TNA, PROB 11/403/137 (1691/2); LMA, CLC/525/MS11316/003 (Cripplegate Without, 1692).

89 Froide, Silent Partners, 31-4. 
kinship, business, apprenticeship and domestic arrangements. Rachel Erskine had held a stall since $1676 .^{90}$ Next to her in the tax list was Elizabeth Kidd, whose sister had a stall as well. In the corner shop, Mary Ludlow and Elizabeth Harrison, both spinsters with the freedom of the Girdlers' and Joiners' Company, respectively, shared 'a shop and a quarter', though by the next quarter's payment that had reduced to ' $3 / 4$ of a shop'. Harrison had earlier joined Ludlow to her first shop's lease in 1687, and the two lived together in the parish of St Margaret Lothbury with two young women apprentices and one servant. ${ }^{91}$ Jane Fielder rented a shop on the west inner pawn in 1689 and soon afterwards requested to have Ann Gregor join her. Gregor, daughter of a Cornish landowner and merchant, had been apprenticed to a goldsmith and had been made free three years before. In 1694, she and Fielder were lodging together in the household of Walter and Ann Holt, along with Lucy Maes, who had been an apprentice of the Spilletts and moved on to work on her own. Her sister was living there too. When Ann Gregor died in 1704, another Fielder woman was one of the witnesses to her will. ${ }^{92}$ The other women in the house were also living with relatives, in one case as a servant. ${ }^{93}$ Mary Barton was another central figure, with a shop on the 'outward part of the west inner pawn' from the 1680s. She and her husband, running a millinery business, took over the shop of Katherine Allen in 1690 when she left the Exchange after thirty years of shopholding. In 1688, Barton also took over the apprentice Frances Bickley when she broke away from her mistress. The Bartons' shop was close to the Spilletts' two shops, where Lucy Maes, Agnes Blennerhassett and their other apprentices would have worked. ${ }^{94}$ Six months after being freed, Agnes Blennerhassett leased her own Exchange shop. ${ }^{95}$ Anne Vanderspritt was in a shop leased by her husband in 1689 after becoming free of the Painter-Stainers. The shops and houses constituted a community of interconnected tenants and apprentices, drawing on longstanding bonds of kinship, obligation and shared occupation and moving flexibly between apprenticeship, shops and houses.

Other records reveal more of apprentices' and shopkeepers' living arrangements. The Exchange separated residential apprenticeship from shopkeeping, but often not by much distance. The tenants of the upper pawn lived predominantly within a few minutes' walk of the building. Of

${ }^{90}$ GL, MS 34042, p. $38 . \quad{ }^{91}$ LMA, COL/CHD/LA/04/049, p. 41.

${ }^{92}$ LMA, CLC/525/MS11316/008; ROLLCO, Anne Gregor; MC, GR 1678-1722, p. 182; TNA, PROB 11/474/432 (1704).

${ }^{93} \mathrm{LMA}, \mathrm{COL} / \mathrm{CHD} / \mathrm{LA} / 04 / 20$, p. 3.

${ }^{94}$ ROLLCO, John Spillett; LMA, CLA/024/05/509. $\quad{ }^{95}$ MC, GR 1678-1722, p. 208. 
the forty-three traceable tenants of the upper Exchange tax list in 1693, nine lived in the same parish and another twenty-four in adjacent parishes. The tax records of the nearby parishes also include others listed as 'exchangemen' or 'exchangewomen'. Both men and women clearly needed shops and homes to be close together, and some may have had shops in their houses as well as in the Exchange. There is a suggestive difference by gender: men who did not live near the Exchange tended to live west of it, towards Holborn and St Paul's, while women tended to live east of it, towards the river and the poorer eastern suburbs. A more marked difference amongst the Exchange tenants is between male shopkeepers as householders in their own right and female shopkeepers as lodgers. Where their status is traceable, in the early 1690 s, male shopkeepers were twice as likely as female ones to be householders, often with substantial stocks worth more than $£ 50 .{ }^{96}$ Nearly all the shopkeepers living in lodgings, in contrast, were women. The same pattern held for men and women working as seamstresses, tailors and milliners elsewhere. In general, women describing themselves as seamstresses were mostly living in lodgings, with no stocks on which to be taxed. Milliners and tailors were overwhelmingly male, and often householders, holding taxable shop stocks; the handful of women milliners in the poll tax lists were also householders. The very few female tailors listed were widows. Inside and outside the Exchange, men and (single) women were engaged in quite different shopkeeping enterprises.

Lodgers' housing arrangements demonstrate the particular lifestyles of working women, which were very different from the old model of residential apprenticeship. Home and work were separate, though they sometimes involved the same people. Twenty-six-year-old Charity Needler, who had requested a lease at the Exchange when she was twenty-three, lodged with her sister and brother-in-law, a gentry couple in St Mildred, Poultry, along with their son and four servants. She was not free of the City, but she took up the freedom of her father's company, the Innholders, by patrimony in 1697, perhaps realising the uses of company membership. ${ }^{97}$ The household of Elias Pledger, an apothecary, and his wife, Elizabeth, included their children, his sister, four female 'servants' (of which at least two were actually apprentices who went on to become free and take a shop together) and three 'lodgers', one of whom, Anne Towse, held an 11-foot shop. ${ }^{98}$ These were the kind of nonnuclear families and complex households that nurtured City trade.

96 Poll Tax 1692.

97 LMA, COL/CHD/LA/04/081, p. 2, Higgins family; LMA, COL/CHD/FR/02/113, no. 97, names a Higgins as 'guardian' on Needler's patrimony application.

98 COL/CHD/LA/04/02/81/16. Bethiah Paradise, one of the apprentices, had been turned over from Henry Duke. 
In multiple occupancy lodgings close to the Exchange, shared housing was a mark of convenience rather than poverty. Rachel Erskine, free in the Merchant Taylors' after her own apprenticeship, was a householder, with rent assessed at $£ 20$ and goods at $£ 50$. She held a shop 'at the Scotch Arms' in the 1670s, was the under-tenant of a 7-foot shop leased by Mrs Hunt in May 1682 and took out her own lease in the 1690s and kept it up for a further twenty years. Erskine shared her house in St Mary Abchurch, near the Exchange, with Frances Antrobus, a twice-widowed Exchange shopkeeper; Frances's daughter, Hester; an apprentice; and two other female servants. Erskine took a series of apprentices and died in 1715 with a good stock of annuities to bequeath. ${ }^{99}$ The Exchange was the ideal place to combine investment and shopkeeping. ${ }^{100}$ Frances Antrobus herself had begun in the Exchange as 'Widow Hulse', marrying the merchant tailor Robert Antrobus during her time as a shopkeeper. She might have been the cousin Frances mentioned in Rachel Erskine's will. Katherine Sommerfield, another wealthy householder and exchangewoman in St Margaret Lothbury, held stock valued at a minimum of $£ 150$. Her household included two female servants (who may have been apprentices or helped in the shop), a family who lodged with her and two other unidentified women. Elizabeth Brewer, another widowed exchangewoman, lived close by, with three children and three servants or apprentices. ${ }^{101}$ The houses of exchangewomen were densely populated and connected like the upper pawn itself. The old pattern of residential apprenticeship had developed a new form, in which the spatial layout of a gallery of shops reflected the networked relations of mistresses, apprentices and journeywomen.

One way of illustrating this is through social network analysis, tracking the bonds between shopwomen. Figure 1.7 illustrates some of the social and contractual bonds that ran alongside the Exchange's shop passages. It foregrounds women and includes shopkeepers and their apprentices but does not include the many tenants for whom no connections have been traced. Most of the bonds are of apprenticeship, because these are the most visible, and it is these which connect a large portion of the tenants to each other. Digitally mapping the ties between people reveals a set of women who act as foci, training several apprentices and creating other connections. Rachel Erskine is at the hub of one series of apprentices, indicating the longevity of her tenure. Ties of executorship added COL/CHD/LA/04/58, p. 10.

100 On women's investment strategies, see Froide, Silent Partners.

101 LMA, COL/CHD/LA/04/049, p. 4; 1692 Poll Tax. 


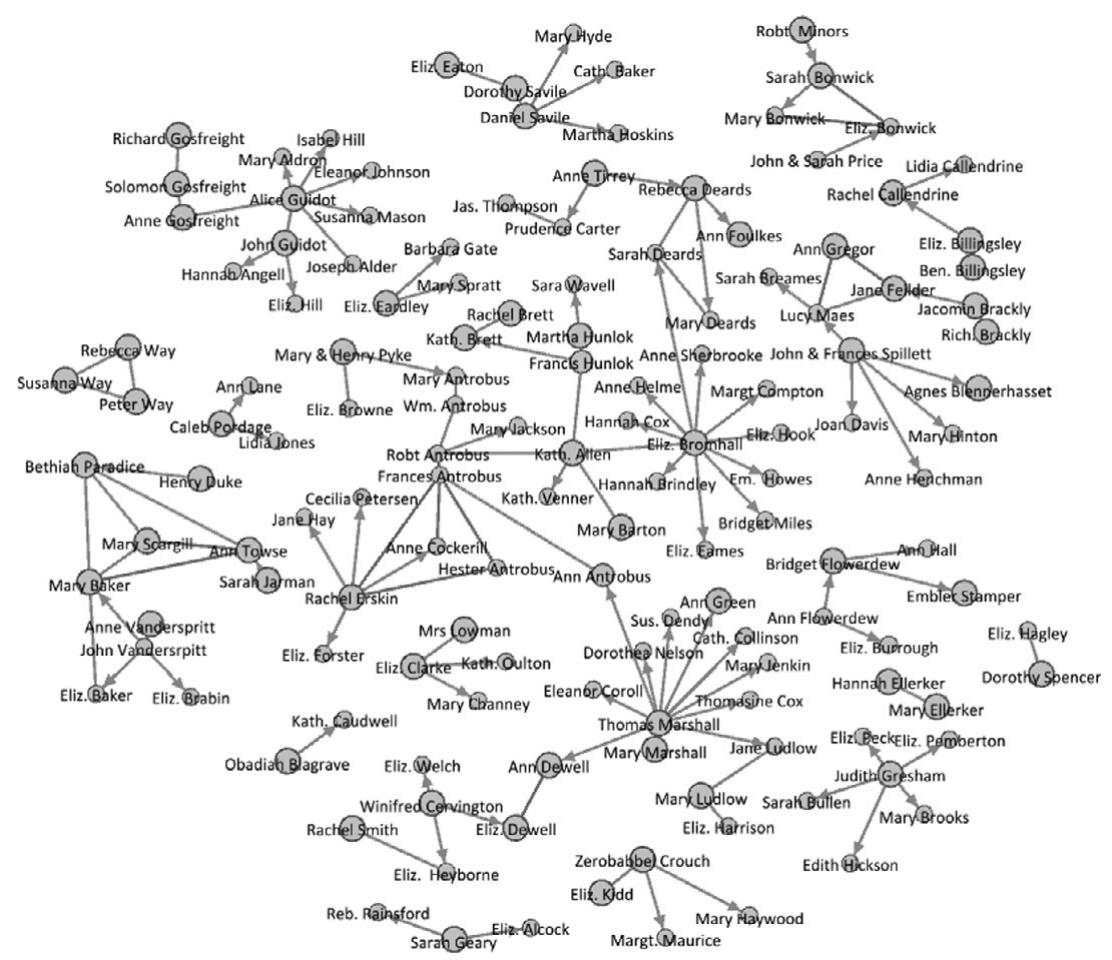

Figure 1.7 Women's connections in the Exchange. Arrows point from mistress to apprentice; larger nodes are shopholders; others are connections without (known) shops. Connections include kin, marriage, housing, shop-sharing and executorship.

Produced with Gephi.

another web of usefulness: Katherine Allen's husband's executors connected her to the Bromhall and Antrobus families. Two networks of four women reflect the shared households near the Exchange: one of four stallholders and apprentices living together, another of four stallholders lodging with an apothecary household. Other clusters represent families of stallholders (Peter Way and his two spinster daughters all held shops), and women who took kin as apprentices, like the Callendrine sisters where the older was apprenticed to Elizabeth Billingsley and the younger to the older. Family ties and business ties are not easily distinguishable.

The dense network indicates the work that apprenticeship did for the business community: it was part of a set of reciprocal ties that bound stallholders and their connections together, providing credit and 
expertise on which to draw, as well as political affiliations like the Bromhalls' Dissenting activities (discussed in Chapter 3): the Exchange was surely better than a guild for sociability, interest and connection. This is also a map of outward reach. Not all these apprentices became free or took their own shops in the building, but the upper pawn acted as a hub which fed out skills and practice into the City's other shops and connections back to the provincial families who aspired to City apprenticeships.

\section{Shopping, Sewing and Selling}

Returning to Ann Gray's inappropriate lace suit takes us back to what the milliners, linen drapers and seamstresses of the Exchange were doing in their shops. They were part of a fashion revolution. The garments of the sixteenth century were predominantly tailored to fit, lasted for years and were inherited or resold and remade. Tailoring, across Europe, was cast as male; women's sewing work was meant to be confined to garments without boning, or inner garments, though the extent of these varied. During the seventeenth century, outfitting came to involve more garments and new fashions in both clothes and accessories. The growing availability of ready-made garments (first for armies, with fixed sizes); the symbolically white linen shirts, sleeves and shifts; changeable accessories like ruffs, hoods and coifs; and comfortable or resizable loose coats for women and children all depended on seamstresses' work. ${ }^{102}$ Childbed linen was another important market. The introduction of the mantua from the 1670s, a one-piece untailored gown that could be made by seamstresses rather than tailors, evolving later into a formal dress that could be arranged over a bodice and petticoat, was once seen as the key to women's growing place in the clothes trade. ${ }^{103}$ It now looks like just one part of women's role in sewing innerwear and, increasingly, outerwear. The dissemination, formal and informal, of specialised sewing skills was part of a broader shift in clothes-making from a culture of tailoring, which was largely male, to one which included and showcased the work of women as seamstresses and, later, milliners. Recent research by Sarah Birt on women in the Merchant Taylors' company reveals the

102 Beverley Lemire, Dress, Culture and Commerce: The English Clothing Trade before the Factory, 1660-1800 (Basingstoke: Palgrave Macmillan, 1997), chapter 2.

103 Clare Haru Crowston, Fabricating Women: The Seamstresses of Old Regime France, 1675-1791 (Durham, NC: Duke University Press, 2001), 36. Examples of the variety of mantuas, from loose kimono-type jackets to more formal gowns, can be seen in 'Lady Clapham's Mantua' in the V\&A collections, and the late seventeenth-century mantua at the Metropolitan Museum of Art, accession no. $33.54 \mathrm{a}-\mathrm{c}$. 
extent to which women were present and working alongside tailors, apprenticed to their wives and working in their shops. ${ }^{104}$

Exact details of what the Exchange shops sold, and particularly the occupations of female stallholders, are rarely recorded. In the upper pawn, shops selling clothes, headwear and other accessories predominated, though the Exchange made strenuous efforts to attract other trades; there was a particular concern amongst shopholders in hard times that too many shops were overlapping. Alongside the many seamstresses and milliners worked Mrs Smith, a linen-seller, and Elizabeth Jenkinson, a spinster who sold spectacles 'and other glasses'. A number of exchangewomen signed a petition of 1696, submitted to the House of Lords in concern about a plan to ban the trade in calico and Bengal silks in London. The trade was managed through the East India Company, and other evidence reveals women's participation in the EIC as stockholders, voters, provisioners and workers on shore, as well as antagonists in property disputes. ${ }^{105}$ The petition described the shopkeepers, male and female, as 'bred in the trade and thereby provided for themselves and families': as Aske Brock and Misha Ewen point out, the expansive global trade of the late seventeenth century brought new opportunities and challenges for women in business, as they chased their money and goods across the widening world.

Exchange shops were small, and girls worked closely with their mistresses, progressing to being left on their own, where their responsibilities for goods and transactions could be daunting. Both tailors and seamstresses worked directly with clients and with proxy shoppers commissioning gowns or buying aprons and handkerchiefs for their sisters, daughters, wives and mothers in the country. Letters, discussions and close observation gave both male and female London shoppers the knowhow to buy for their families. ${ }^{106}$ The scale of some stallholders' stock suggests they had bigger shops elsewhere, but many women's shops seem to have been their only one. Although small, shops could be elaborately fitted. Abraham Dudley, who sold Indian chintz nightgowns, claimed to have spent 'near $£ 200$ ' in fitting up his shop to make it 'an ornament to

${ }^{104}$ Sarah Birt, 'Women, Guilds and the Tailoring Trades: The Occupational Training of Merchant Taylors' Company Apprentices in Early Modern London', The London Fournal 46, no. 2 (May 2021): 146-64.

105 Sharpe, 'Gender at Sea'; Aske Laursen Brock and Misha Ewen, 'Women's Public Lives: Navigating the East India Company, Parliament and Courts in Early Modern England', Gender $\mathcal{E}$ History 33, no 1 (March 2021): 3-23.

106 Danae Tankard, Clothing in 17th-Century Provincial England (London: Bloomsbury, 2019), chapter 6. 
the Exchange'. ${ }^{107}$ Testimony about a theft from another Exchange shop indicates that it had room for customers to sit down while they shopped. Elizabeth Jones had been sitting in a chair in Mrs Bassett's shop, bargaining for $£ 10$ worth of bone lace to make sleeves, and tried to conceal it under her petticoat. When she got up, the lace caught around her legs and made her theft obvious; she got away but was caught nearby in Castle Alley. ${ }^{108}$ The small size and ready surveillance of Royal Exchange shops, as well as the long route from shop to exit, seem to have made them less vulnerable to the habit of shoplifting that drove shopkeepers to lobby for an Act against it in 1699. Rather, their shops ran heavily on credit or partial credit, as indicated by the considerable debts in the inventories and wills of stallholders; the wealthier Royal Exchange customers had other ways of shopping without paying. ${ }^{109}$

Bargaining looms large in the numerous shoplifting cases in the Old Bailey: 'cheapening' provided cover for dragging out a purchase. It was evidently critical to the skills of both shopper and shopkeeper. ${ }^{110}$ Ann Gray's troubles with credit, and the accusations levelled at other Exchange girls, where transactions were short of pence and sixpences, were individually recognisable and also reflect the shortage of ready cash in late seventeenth-century London. Shopkeepers often used their own tokens to replace it. An epidemic of coin clipping (in which women were heavily involved) meant, too, that silver coins no longer represented their value. The 1696 Recoinage Act demanded that legal currency be punched with a hole to mark it as unclipped, giving rise to bawdy ballads fantasising about lusty girls rushing to be 'punched'. ${ }^{111}$ At the same time, shops ran on credit and kept large tabs running for their credit customers; the difference between shoplifters and credit shoppers was not always obvious. Cash transactions could be tricky, and managing them meant shopkeepers and apprentices navigating the line between credit, cheating and theft.

In 1678, an anonymous woman authored Advice to the Women and Maidens of London, a women's guide to accounting, printed by Benjamin Billingsley, a stationer with a shop by the Exchange. Billingsley's wife, Deborah, sold medicines and had, it was said, sufficient expertise to keep

107 MC, GR 1678-1722, p. 4.

108 Old Bailey Proceedings Online (www.oldbaileyonline.org), 30 August 1694, t16940830-4.

109 Jonah Miller, 'Review of Shoplifting in Eighteenth-Century England', Reviews in History, no. 2329, www.reviews.history.ac.uk; Shelley Tickell, Shoplifting in Eighteenth-Century England (Woodbridge: Boydell \& Brewer, 2018).

110 Helen Berry, "Polite Consumption": Shopping in Eighteenth-Century England'. Transactions of the Royal Historical Society 12 (2002): 375-94.

111 Lili Loufborrow, 'The Punching-Office: Where 17th-Century Ladies Go for Sex', www .thehairpin.com/2011/04/the-punching-office-where-17th-century-ladies-go-for-sex/. 
her husband's shop going in his absence. ${ }^{112}$ His sister, Elizabeth, was a seamstress in the Scriveners' Company, who took her own apprentices, including Rachel Callendrine, who then became free and opened her own shop in the Royal Exchange. Perhaps one of these women wrote the Advice. ${ }^{113}$ The book reconstructs typical shop debts and credits in minute detail, demonstrating how double-entry bookkeeping could keep track of the kind of long, transferrable debts that shopkeepers were apt to live and die with. The reader is asked to 'Imagine an Exchange-Woman, Shop-keeper, or the like, newlly entring upon Trade'. First, she draws up an inventory of her estate: $£ 60$ in ready money, $£ 8$ of black alamode (a thin, plain-woven lustred silk used for scarfs and hoods), twenty dozen women's gloves worth $£ 16$ and a debt of $£ 20$ from Mrs Martha Thorpe. That debt from Mrs Thorpe is then augmented by her taking another $£ 35$ worth of gloves; when our shopkeeper buys 60 ells of Bag-Holland (fine quality linen) and four pieces of cambric for a total of $£ 23$ from James Jones, she pays him $£ 12$ 10s in cash and assigns him $£ 10$ 10s of Mrs Thorpe's debt. She has the linen cut up and made into handkerchiefs, cravats and cuffs, paying the seamstress $£ 210$ s for her work. She meets a merchant going to Barbados, who offers two hogsheads of sugar in exchange for half her stock of linen. The slave trade was only one step away from the Exchange shops, its transactions worked out on the Exchange floor and in Cornhill's coffee houses. ${ }^{114}$ Our exchangewoman's trade is enabled by the demand for luxury goods and more disposable fashion, connecting the transatlantic forces of commerce and investment with Londoners and provincial customers. On a smaller scale, the whole business of debt management and accounting was a critical skill for shopkeepers, and here it also overlaps with apparently pre-existing debts between women; the micro-economies of provincial England were sustained by such loans, with single women and widows prominent in them. ${ }^{115}$

112 Elizabeth Lane Furdell, Publishing and Medicine in Early Modern England (University of Rochester Press, 2002), 109. The report is from John Dunton.

$113 \mathrm{LMA}, \mathrm{COL} / \mathrm{CHD} / \mathrm{FR} / 02 / 2$, no. 31; Rachel Callendrine's indenture to Elizabeth Billingsley in 1674 was witnessed by Benjamin Billingsley. Deborah Billingsley is a likelier potential author, as the text refers to managing her father's household when she grew up, while Elizabeth's father died before she was eleven.

114 Advice to the Women and Maidens of London Shewing, That Instead of Their Usual Pastime, and Education in Needlework ... It Were Far More Necessary and Profitable to Apply Themselves to the Right Understanding and Practice of the Method of Keeping Books of Account ... by One of That Sex (London: Benjamin Billingsley, 1678), 21-2. This book is discussed further in Chapter 3.

115 Muldrew, Economy of Obligation. 
The contents of London shops have left some record in accounts and probate inventories. A chancery case at the end of the seventeenth century included as evidence the account book of a Miss Goreing, a rural gentlewoman living in London. In the second half of 1697, she bought flannel and dimity for petticoats; 'Bengall' for two frocks; muslin for lining; six pairs of shoes; two sarsnet hoods; an Indian satin gown 'lyned with Pertian' for 15s; fine holland to make shifts, pins and tape; and fans, ribbons and gloves. She had two coats made and spent $£ 5$ on rich silk. Silk loomed large in her spending, and she also paid a dancing master, but more ordinary purchases involved muslin and holland, and hoods, ribbons and gloves, as well as mourning for herself and two servants when her uncle died. Her maid's wages for the half-year were $£ 1 .{ }^{116}$ A more precise picture of shop contents can be found in the probate inventory of Herbert Allen, the haberdasher who, with his wife Katherine, took a series of apprentices, boys and girls, to work in their Exchange shop in the 1660s. Allen's inventory was drawn up in 1668, seemingly while the shop was relocated at the New Exchange after the Fire. It records an extensive list of ready-made goods, worth over $£ 1,000$, 'in the shop on the Exchange known by the sign of the Parrett'. There was $£ 300$ worth of various kinds of lace and numerous bundles of holland, lawn and cambric; alamode and lutestring silks; and 40 ells of yellow birdseye, a cheaper patterned wool which sold at $1 \mathrm{~s} 6 \mathrm{~d}$ an ell. The Allens were also selling ready-made clothes: laced, linen or plain suits (14s to $52 \mathrm{~s}$ ); waistcoats and undergarments, including parcels of 'old fashioned' linen for women; 'childbed linen' $(£ 3)$ and children's linen. There were countless accessories too: women's sleeves, twenty dozen children's caps, aprons, fans, neckcloths and masks. ${ }^{117}$

Apprentices working in such a shop would need a thorough knowledge of the range of goods and the cost of different weights and classes of textiles, as well as how to navigate its doubtless crammed shelves and parcels of goods. Herbert Allen's appraisers, Robert Antrobus and Thomas Bromhall, were themselves skilled and knowledgeable men of the Exchange and its goods. Debts were enormous too: Allen had over $£ 2,000$ of outstanding debts, including sums from several regular customers, the Duke of Buckingham and the Countess of Bedford, one of the 'Beauties' of Charles II's court. The Allens' shop, with its series of gentry apprentices, was at the forefront of elite shopping in the Exchange.

The last item on Herbert Allen's shop inventory was $£ 512$ s worth of 'holland fabric in the hands of work women to make up', reflecting, like

116 TNA, C 114/182.

117 LMA, CLA/002/02/01/0570 (3 October 1668). An ell was just over a yard. 
Advice to Women, the degree to which Exchange shops and milliners depended on seamstresses working elsewhere. The putting-out system employed an invisible number of women in supplying shops, at rates which were dropping; apprenticeship as a seamstress offered the potential of moving to the upper end of the system, supplying customers directly or running a shop. One of Hester Pinney's letters from her sister-in-law Mary describes 'the baggarly working to the Change which is now grown very low and Contemptible'. ${ }^{118}$ Mary Pinney may have been referring to all the Exchanges, or just the New Exchange where she and Hester Pinney worked; her assessment indicates the growing autonomy of the seamstresses outside the City, around Covent Garden, Charing Cross and the Strand, where several of the women in the Merchant Taylors' Company had their shops and which may have provided longer careers as well as better rewards than the small Exchange shops.

The Royal Exchange had also long been a centre for portrait painters. In the later seventeenth century, several members of the Painter-Stainers' Company held shops there, including the portraitists John Vanderspritt and Daniel Savile, who drew Pepys. Their wives had shops too and they took female apprentices, some of whom went on to start their own shops. Women did train painter-stainers, as well as practising as painters: Helen Draper's examination of the painting trade in seventeenth-century London reveals at least one who took male apprentices. ${ }^{119}$ In the Exchange, though, the evidence shows millinery and drapery running alongside the painting trade. The interface between husbands' and wives' businesses remains opaque. Daniel Savile took six apprentices, the first two boys and the rest girls; he requested a lease in the Royal Exchange in 1689 , and his wife, Dorothy, held a shop there in the 1690s, jointly with Elizabeth Eaton. ${ }^{120}$ Daniel and Dorothy's final apprentice, Elizabeth Calverley, completed her apprenticeship after Daniel's death, became free and, in 1703, was holding an Exchange shop with Samuel Dudley. All the signs are that Dorothy, more than Daniel, was the active employer here, and her shop was in the upper Exchange alongside milliners and haberdashers. The Painter-Stainers were tied into the Exchange network of social and business contacts, suggesting a shared trade amongst the

118 Bristol University Special Collections, Pinney Letters, Red Box 2 folder VII, Mary Pinney to Hester Pinney, 7/2/1694/5.

119 Helen Draper, 'Mary Beale and Art's Lost Laborers: Women Painter Stainers', Early Modern Women 10, no. 1 (2015): 141-51.

120 Kate Loveman, 'Samuel Pepys's First Portrait Painter: Daniel Savile and Portraiture for the Middling Sort in Restoration London', fournal of the Warburg and Courtauld Institutes 81 (2018): 269-79; MC, GR 1678-1722, p. 208. 
wives. Other couples in the same company followed the same route, in varying proportions. John Vanderspritt and his wife, Elizabeth, took two girls and two boys between 1688 and 1693: first a boy, then a boy and a girl, then another girl. His sister Anne had a shop in the Exchange as well. Francis and Martha Hunlok took three female apprentices between 1668 and 1675, and Martha took another one in her widowhood, a gentleman's daughter from London, at which point her trade is described as milliner. Judith Gresham, another widow taking apprentices, was also in the Painter-Stainers'; her own two daughters, Mary and Judith, remained single and described themselves in their wills as 'spinster and trader'. Thomas Marshall and his wife, Mary, took eighteen apprentices from 1676 to 1712 , where all but four of them were girls. ${ }^{121}$

The last of Thomas and Mary Marshall's apprentices left extensive evidence of her career and connections. Ann Dewell was the daughter of a gentleman from Worcester, apprenticed in 1699; her two sisters were also apprenticed to London guilds. Alongside Ann Dewell in the Marshall business worked Mary Dix, another gentry daughter from Liverpool, who was apprenticed a few years later in 1704. By this time the Marshalls had a shop on the upper floor of the Royal Exchange, and when Ann Dewell completed her apprenticeship and became free, she took a shop herself, with Mary Dix as partner. ${ }^{122}$ The Exchange was a stronghold of female business partnerships. Some such relationships were flexible, others lasted years; one advantage was to allow women without the freedom to draw on the privileges of those with it. In contrast to trading with a husband, it allowed equitable sharing of responsibility as well as debts, and while some partners were single, others kept up business partnerships alongside their marriages, enjoying with them a protection from the constraints of coverture. ${ }^{123}$ In the case of Dewell and Dix, Mary Dix died young in 1718 and left details of their partnership in the will she wrote when she became ill. It partook of the riskiest features of Exchange shops, accumulating considerable debts:

and whereas my partner Mrs Anne Dewell and myself had sundry debts due and owing from severall persons to us at Christmas 1717 amounting in the whole to 1017 pounds by the accompt of our debts then taken appears a good part of which are yet standing out And whereas since taking the said accompt of the said debts other fresh debts have become due to us and fresh credit must be given soe long as we carry on our joint trade. ${ }^{124}$

${ }^{121}$ LAA. ${ }^{122}$ LMA, CLC/525/MS11316/016.

123 Alexandra Shepard, 'Minding Their Own Business: Married Women and Credit in Early Eighteenth-Century London', Transactions of the Royal Historical Society 25 (December 2015): 53-74.

124 TNA, PROB 11/365/519 (1718); PROB 11/818/476 (1755). 
Ann Dewell went on trading and took her own apprentices: her much younger sister, Rebecca, in 1725; Oriana Michell; and Carolina Banson, a clerk's daughter from London who took an apprentice herself and then married. Ann Dewell's will indicates the networks that these years of business generated: she had her will proved by Henry Marshall, Thomas and Mary's son, who was just completing his own apprenticeship with his father as Anne arrived in 1699, and left money to a Mrs Marshall (perhaps Henry's sister, or wife) and to Mrs Banson, probably her own ex-apprentice.

The Exchange, then, offered an ideal forum for the honing of appearance and self-presentation that both portraiture and millinery provided; in these working households, studios and shops, the overlap between painting, drawing and sewing was surely a benefit to gentry girls in service.

Daniel Defoe's nostalgic vision of 1727 saw the present as characterised the 'squandering of trade' in the City; his seventeenth century, by contrast, was the time of 'the two great Centers of the Women Merchants ... The Royal Exchange, and the new-Exchange in the Strand'. Once full of 'flourishing milliners', they had become warehouses and insurance offices. ${ }^{125} \mathrm{By}$ the second quarter of the eighteenth century, the place of trade in the City seemed to be disappearing. Women merchants are an addendum to Defoe, at the very end of his long parade of City trades, but his sense of the Exchanges as a centre of female trade is important. For a hundred years, the location of the Royal Exchange put its shops at the heart of other City businesses and brought guilds and women merchants, shopping and investing, intimately together.

The shopwomen of the Exchanges were subject to sexualisation in both print and person. A number of late seventeenth-century pamphlets represented the barter of shopkeeping in sexual terms. James Turner has acutely summed up the commodification of female entrepreneurs in libertine satire: 'the sites of women's agency are interchangeable in the libertine imagination', and all female enterprise could be interpreted as cover for the sale of women themselves. ${ }^{126}$ The Strand Exchanges were most heavily appropriated, but the idea of shopping galleries as sexual may have cast a rhetorical shadow over the rest too. Pepys's accounts of his trips to Westminster Hall, the New and the Royal Exchanges record the variety of business he transacted at each, a combination of meetings, shopping, and leaving and collecting Elizabeth, his wife. At the New Exchange, where they spent the most shopping time,

125 Daniel Defoe, The Complete English Tradesman: In Familiar Letters (1727), 166.

126 Turner, "News from the New Exchange", 419-39. 
Samuel sometimes left her to shop while he walked up and down talking; on other occasions he shopped alone, or they went together. At Westminster Hall, he made a particular habit of visiting the shops of his 'sweethearts', sometimes taking them off to drink elsewhere. Amongst them was Betty Martin, who held a draper's stall; visiting her there in early 1666, he was relieved to discover her child was to be named Charles, meaning he was not to be the godfather and freeing him from the suspicion of paternity. ${ }^{127}$ At the Royal Exchange, nearer home, Samuel targeted Mary Batelier, who he first encountered in April 1665, when buying a pair of cotton stockings at the shop of her brother, who he took to be her husband:

At noon to the Change, and then went up to the Change to buy a pair of cotton stockings, which I did at the husband's shop of the most pretty woman there, who did also invite me to buy some linen of her; and I was glad of the occasion and bespoke some bands of her, entending to make her my seamstress - she being one of the prettiest and most modest-looked women that ever I did see.

On another occasion, he came back to see if she was there, 'poor pretty woman', and 'saluted her over her counter in the open Exchange above' ${ }^{128}$ Mary Batelier's 'invitation' gives a hint of the social intercourse expected of women in the Exchange, another kind of work that seems comparable to the 'emotional labour' traced by Arlie Hochschild in modern coffee shops and service industries. ${ }^{129}$ More precisely, it was a sexualised labour, where working at a certain look - amplified in the depositions that underline the need for tidiness and good dress - might also involve calling out and calling attention to both human and linen goods. ${ }^{130}$ Several later commentaries describe women in the Exchange calling out to their customers; in the Spectator in 1712, Addison described how 'the dear Creatures called to me to ask what I wanted, when I could not answer, only To look at you'. ${ }^{131}$ Alongside the sexualisation of seamstresses, though, we should consider also the actual emotional and sexualised labour, the work of the look, that women were expected to put in. Pepys's other references to Mary Batelier give a glimpse of her life outside the shop. The family lived at Crutched Friars, close enough to the Navy Office where the Pepyses lived to talk

127 Pepys, Diary, 9 March 1665/6. ${ }^{128}$ Pepys, Diary, 2 April and 20 December 1665.

129 Arlie Russell Hochschild, The Managed Heart: Commercialization of Human Feeling (Berkeley: University of California Press, 2003).

130 Chris Warhurst and Dennis Nickson, "Who's Got the Look?" Emotional, Aesthetic and Sexualized Labour in Interactive Services', Gender, Work E Organization 16, no. 3 (2009): 385-404.

131 Saunders, The Royal Exchange, 207. 
to them across the roof leads where the Pepyses had made a balcony. ${ }^{132}$ Mary visited Mrs Pepys, came with her brother to play cards and have supper, recommended a controversial sermon and was a bridesmaid at Pepys's maid Jane's wedding in $1669 .{ }^{133}$ That, as a sister of a stallholder, she does not appear in the Exchange records is a reminder of how many other women worked in the shops.

This feminine and feminised shop world sat in the midst of the mercantile city. Its most obvious counterpart, apart from the downstairs Exchange, was the coffee-house, another point of contact for politicians and merchants. By the late seventeenth century, the Exchange was surrounded by coffee-houses, differentiated by political and religious affiliation and treated, by both contemporaries and historians, as the stage for masculine political conversation. ${ }^{134}$ The coffee-house world provided, too, a place where brokers and jobbers could connect. In contrast to the coffee house's masculinised sphere, the Exchange offered heterosociality, female trade and easy interchange between the exchanges of financial trading and those of millinery. Coffee-houses too were run by women: at least eleven women are listed as coffee-house keepers in the Poll Tax list of 1692, along with twenty-two 'coffee-women' who sold coffee in stalls or on the streets. But their clientele appears to have been predominantly, if not entirely, male. This is not to oppose shops and politics or containment and free movement. The Whig connections of some Exchange tenants suggest that, like coffee houses, it might also have reflected Whig dominance in City government and the Nonconformist merchants' interests of the 1670 s and 1680s. Likewise, while coffee-house culture has been neatly mapped onto the normative masculine public sphere, the Exchange was also seen as a place of loose talk. The actual spatial range of late seventeenth-century London women seem to have been at least as broad as that of their male peers, as they travelled through the metropolis for work and leisure. ${ }^{135}$ Rather, the Exchange complicates the distinction of public/private yet again. The Exchange/coffee-house matrix also suggests a way to think about racially marked products in the market of late seventeenth-century London.

132 Pepys, Diary, vol VII, 15 n. 4.

133 Pepys, Diary, 14 February 1665/6; 18 January 1666/7; 27 March 1669.

134 Brian Cowan, 'What Was Masculine about the Public Sphere? Gender and the Coffeehouse Milieu in Post-Restoration England', History Workshop fournal 51 (2001): 127-57; Joseph Monteyne, The Printed Image in Early Modern London: Urban Space, Visual Representation, and Social Exchange (Aldershot: Ashgate, 2007), 36.

135 Robert Shoemaker, 'Gendered Spaces: Patterns of Mobility and Perceptions of London's Geography, 1660-1750', in Imagining Early Modern London: Perceptions and Portrayals of the City from Stow to Strype, 1598-1720, ed. J. F. Merritt (Cambridge University Press, 2001). 
Exchangewomen sold white linen to (largely) white customers, some of whom traded in and benefitted from slavery; meanwhile, the blackness of coffee was fantasised as contagious to English stomachs (and, by extension, the dissent of the coffee house a risk to loyalism) and the regular image of the Turk's Head that was used to sell it offered a persistent exotic other to the London consumer. ${ }^{136}$ Alongside such images, black workers were integrated into London households: William Batelier, Mary's brother, had two black servants, one of whom, Doll, regularly dressed the Pepyses' meat and danced jigs with other guests at a family wedding. ${ }^{137}$

The Exchange women were not typical of women's work in seventeenth-century London, or even of seamstresses, milliners and linen-sellers. They were subject to, and sometimes mistresses of, a spatially and economically particular set of power dynamics, in which they laid claim to the rights of the City to work in a circumscribed yet influential place. The skills of sewing and selling that were shared there had reverberations through London's fashion economy. The spatial organisation of their labour and social lives adds a key dimension not only to the Exchange world but to the notions of male, female and mixed space that were in the process of being established in the late seventeenth-century city. That space was created through consumption and labour. At its heart was an economy of credit: earned through trust, bartered between women and accumulated by women's management of shops, goods and debts.

${ }^{136}$ Monteyne, Printed Image, chapter $1 . \quad{ }^{137}$ Pepys, Diary, 5 April 1669. 